\title{
A Multivalent ICAM-1 Binding Nanoparticle which Inhibits ICAM-1 and LFA-1 Interaction Represents a New Tool for the Investigation of Autoimmune-Mediated Dry Eye
}

\author{
Pang-Yu Hsueh ${ }^{1, \dagger}$, Yaping Ju ${ }^{1, \dagger}$, Adrianna Vega ${ }^{1,+}{ }^{\text {, Maria C. Edman }}{ }^{2}$, , J. Andrew MacKay ${ }^{1,3, *}$ \\ and Sarah F. Hamm-Alvarez ${ }^{1,2, * \text { (D) }}$ \\ 1 Department of Pharmacology and Pharmaceutical Sciences, School of Pharmacy, \\ University of Southern California, Los Angeles, CA 90033, USA; pangyuhs@gmail.com (P.-Y.H.); \\ yju@usc.edu (Y.J.); vega@usc.edu (A.V.) \\ 2 Department of Ophthalmology, USC Roski Eye Institute, University of Southern California, \\ Los Angeles, CA 90033, USA; edman@usc.edu \\ 3 Department of Biomedical Engineering, University of Southern California, Los Angeles, CA 90089, USA \\ * Correspondence: jmackay@usc.edu (J.A.M.); shalvar@usc.edu (S.F.H.-A.) \\ + These authors contributed equally to the manuscript and share first authorship.
}

Received: 13 March 2020; Accepted: 12 April 2020; Published: 15 April 2020

\begin{abstract}
The autoimmune disorder, Sjögren's syndrome (SS), is characterized by lymphocytic infiltration and loss of function of exocrine glands such as the lacrimal gland (LG) and salivary gland. SS-associated changes in the LG are associated with the development of autoimmune-mediated dry eye disease. We have previously reported the accumulation of intercellular adhesion molecule 1 (ICAM-1) in the LG of Non-Obese Diabetic (NOD) mice, a murine model of autoimmune-mediated dry eye in SS, in both LG acinar cells and infiltrating lymphocytes. ICAM-1 initiates T-cell activation and can trigger T-cell migration through binding to lymphocyte function-associated 1 antigen (LFA). To modulate this interaction, this study introduces a new tool, a multivalent biopolymeric nanoparticle assembled from a diblock elastin-like polypeptide (ELP) using the S48I48 (SI) ELP scaffold fused with a mouse ICAM-1 targeting peptide to form IBP-SI. IBP-SI forms a multivalent, monodisperse nanoparticle with a radius of $21.9 \mathrm{~nm}$. Unlike the parent SI, IBP-SI binds mouse ICAM-1 and is internalized by endocytosis into transfected HeLa cells before it accumulates in lysosomes. In vitro assays measuring lymphocyte adhesion to Tumor Necrosis Factor TNF- $\alpha$-treated bEnd. 3 cells, which express high levels of ICAM-1, show that adhesion is inhibited by IBP-SI but not by SI, with IC $\mathrm{IC}_{50}$ values of $62.7 \mu \mathrm{M}$ and $81.2 \mu \mathrm{M}$, respectively, in two different assay formats. IBP-SI, but not SI, also blocked T-cell proliferation in a mixed lymphocyte reaction by $74 \%$ relative to proliferation in an untreated mixed cell reaction. These data suggest that a biopolymeric nanoparticle with affinity for ICAM-1 can disrupt ICAM-1 and LFA interactions in vitro and may have further utility as an in vivo tool or potential therapeutic.
\end{abstract}

Keywords: elastin-like polypeptide; intercellular adhesion molecule-1; Sjögren's syndrome; dry eye; lymphocyte function-associated 1 antigen

\section{Introduction}

Sjögrens' syndrome (SS) is an autoimmune disease associated with lymphocytic inflammation of exocrine secretory tissues including the lacrimal gland (LG) and salivary gland (SG), reduction of glandular secretory capacity and consequent development of severe dry eye and dry mouth [1]. The autoimmune inflammation in SS may also affect other organ systems such as the kidney, liver and 
brain, while SS patients have a significantly increased incidence of B-cell lymphoma [2]. Currently, there is no effective and specific therapy for the autoimmune-mediated dry eye associated with SS due to an incomplete understanding of disease pathology in the LG [3,4], and also due to the inability to target therapies which may reduce lymphocytic infiltration to the LG. As is typical of other autoimmune disease patients, patients with SS are often treated with topical, oral, or intravenous immunomodulatory agents, including steroids and cyclosporine $\mathrm{A}$, to suppress systemic and local T-cell proliferation $[2,5,6]$. Work in a murine model of SS has shown that the immunomodulatory agent, rapamycin, also has potential in treating the autoimmune inflammation of LG and in improving tear flow $[7,8]$. Herein, we report on a new tool, the use of a multivalent nanoparticle that is capable of inhibiting interactions critical for immune cell migration into the LG. The target of this multivalent nanoparticle is intercellular adhesion molecule-1 (ICAM-1, or CD54).

ICAM-1 is a cell-surface glycoprotein member of the immunoglobulin (Ig) superfamily, and consists of five extracellular Ig-like domains, a transmembrane domain, and a short cytoplasmic domain [9]. It exists in two isoforms: membrane-bound and soluble ICAM-1 (sICAM-1) [10]. ICAM-1 is constitutively expressed at low levels on the surface of most cells; its upregulation is induced by interleukin-1 (IL-1), interferon- $\gamma$, and tumor necrosis factor (TNF)- $\alpha$ [11] in response to inflammatory stimuli. As the homing receptor for leukocytes and macrophages, ICAM-1 is involved in lymphocyte migration, co-activation of T- and B -cells, and leukocyte extravasation into lymphoid and inflamed non-lymphoid tissues through interactions with $\beta_{2}$ integrin lymphocyte function-associated antigen-1 (LFA-1, $\alpha_{\mathrm{L}} \beta_{2}$, or CD11a/CD18) and macrophage 1 antigen [12]. ICAM-1 expression is significantly correlated with the progression of many inflammatory diseases. For example, monitoring the concentration of circulating sICAM- 1 can improve the prediction of diseases such as atherosclerosis [13,14], diabetes [15,16], and cerebral malaria [17].

In terms of SS, biopsies from the conjunctiva, LG, and SG of human and SS-susceptible animal models (e.g., mouse, rat, and canine) exhibit lymphocytic infiltration with increased expression of various inflammatory and immune activation markers such as ICAM-1, LFA-1, and major histocompatibility complex class II antigens [18,19]. In a murine model of the autoimmune-mediated dry eye characteristic of SS, the male Non-Obese Diabetic NOD mouse, ICAM-1 is highly expressed in the LG, both in LG acinar cells (LGAC) and in infiltrating immune cells [20]. This finding suggests that ICAM-1 might constitute a target for the disruption of immune cell homing to the LG. Studies targeting ICAM-1/LFA-1 interactions as a strategy to develop novel anti-inflammatory therapies have mainly focused on other immunoregulatory conditions, such as graft rejection, atopic dermatitis, psoriasis, and rheumatoid arthritis [21-23]. However, an ophthalmic solution, $5 \%$ Lifitegrast (Xiidra ${ }^{\circledR}$ ), is also approved for the treatment of dry eye. This novel integrin antagonist mimics the binding epitope of ICAM-1, thus reducing the binding of LFA- 1 to endogenous ICAM- 1 and inhibiting downstream inflammation [24].

Our group recently showed that the addition of a single ICAM-1 binding peptide (IBP) to a protein nanocarrier administered intravenously can transiently increase the accumulation of this nanocarrier in the LG in the NOD mouse model of autoimmune-mediated dry eye, relative to the untargeted nanocarrier [20]. We hypothesized that a nanoparticle containing multiple copies of IBP might be able to functionally disrupt ICAM-1 and LFA interactions in the LG. As the first step in testing this hypothesis, an anti-mouse IBP [25] was fused to an elastin-like polypeptide (ELP) biopolymer to assemble a nanoparticle. Mimicking the repetitive hydrophobic domains of human tropoelastin, ELPs are composed of a repeating pentameric motif (Val-Pro-Gly-Xaa-Gly) $n$, where Xaa can be substituted with amino acids that possess different hydrophobicity or hydrophilicity, thus changing the assembly properties [26]. ELPs phase separate above a lower critical solution temperature, which can be tuned by the selection of Xaa and $n[26,27]$. The backbone ELP used in this study was a diblock copolymer with 48 serine (S48) and 48 isoleucine (I48) guest residues (S48I48, SI). SI has previously been shown to assemble a nanoparticle capable of sequestering hydrophobic drugs such as rapamycin for therapeutic administration in vivo in a mouse model of SS $[7,28]$. Expressed and purified from 
E. coli, the diblock copolymer IBP-SI construct assembles into a stable nanoparticle with biophysical properties comparable to the parent SI, but with the additional ability to bind and to be internalized by the mouse ICAM-1 receptor expressed in HeLa cells, as well as to engage with the endogenous human receptor. Finally, IBP-SI, but not SI, impairs lymphocyte adhesion to cultured bEnd.3 endothelial cells expressing high levels of ICAM-1, as well as T-cell proliferation in response to antigen presentation in a mixed cell reaction.

\section{Results}

\subsection{IBP-SI Forms Nanoparticles at Physiological Temperature}

The genetically engineered protein-polymer termed IBP-SI was expressed in BLR(DE3) competent E. coli and purified from E. coli lysates by the induction of ELP-mediated phase separation. IBP-SI consists of a mouse ICAM-1 targeting peptide, which binds murine ICAM- 1 and inhibits ICAM-1-mediated intercellular adhesion [25]. IBP was linked to the N-terminus of an ELP called SI, which is comprised of an N-terminal hydrophilic peptide motif, (Val-Pro-Gly-Ser-Gly) 48 , and a C-terminal hydrophobic peptide motif, (Val-Pro-Gly-Ile-Gly) ${ }_{48}$ (Table 1). Like SI, IBP-SI was anticipated to form a core-shell nanoparticle above its critical micelle (first) temperature, $T_{t 1}$, (Figure 1B) and a bulk coacervate above its higher (second) transition temperature, $T_{t 2}$. Gel electrophoresis using SDS-PAGE and staining with $10 \%(w / v)$ copper chloride confirmed the molecular mass and purity of the IBP-SI and SI ELPs, showing that the purity of IBP-SI was $87.92 \%$ compared to $92.64 \%$ of its SI counterpart (Figure 1A). Molecular weights of SI and IBP-SI were confirmed by matrix-assisted laser desorption/ionization time of flight mass spectrometry and were $39.5 \mathrm{kDa}$ and $41.4 \mathrm{kDa}$, respectively, within $0.3 \%$ of their expected weights (Table 1; Figure 1A).

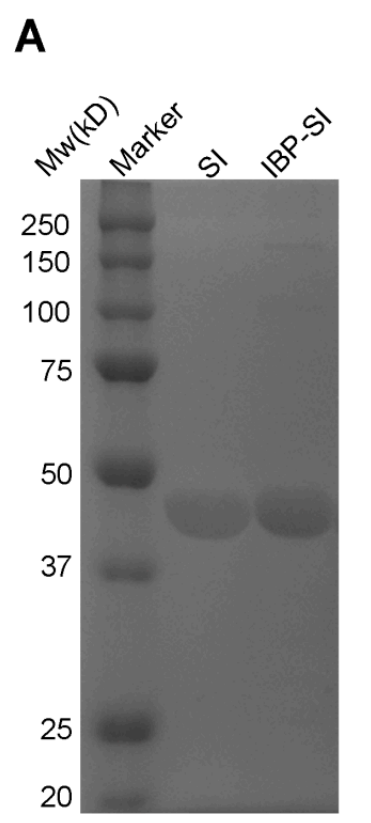

B

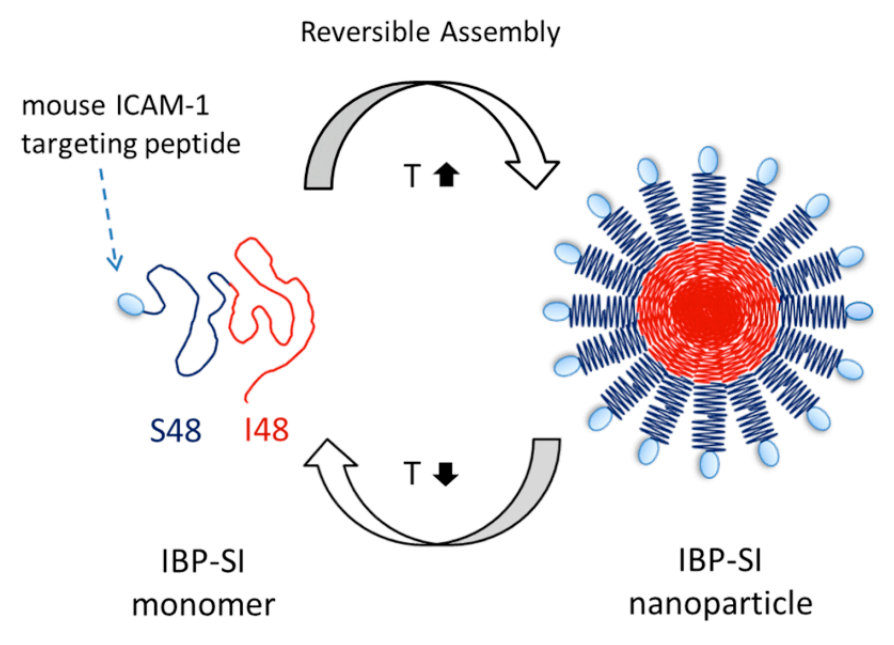

Figure 1. Characterization and design of an elastin-like polypeptide (ELP) nanoparticle to target intercellular adhesion molecule 1 (ICAM-1). (A) Purified ELPs were resolved on 4-12\% SDS-PAGE gels and stained with $10 \%(w / v)$ copper chloride, revealing bands consistent with the estimated molecular weight (Mw) of SI (39.6 kD) and IBP-SI (41.5 kD). (B) An ICAM-1 binding peptide (IBP) was appended to the amino-terminus of a diblock copolymer consisting of the hydrophilic ELP (VPGSG) 48 , illustrated as S48 and shown in dark blue, and the hydrophobic ELP (VPGIG) 48 , illustrated as I48 and shown in red, designated IBP-SI. IBP-SI assembles into nanoparticles at physiological temperatures $\left(37^{\circ} \mathrm{C}\right)$. 
Table 1. Biophysical characteristics of evaluated ELP protein-polymers.

\begin{tabular}{|c|c|c|c|c|c|c|}
\hline Label & Amino Acid Sequence ${ }^{a}$ & $\begin{array}{l}T_{t 1} b \\
\left({ }^{\circ} \mathrm{C}\right)\end{array}$ & $\begin{array}{l}T_{t 2}{ }^{\mathrm{c}} \\
\left({ }^{\circ} \mathrm{C}\right)\end{array}$ & $\begin{array}{c}\text { Expected } \\
\text { MW }^{d}(k D a)\end{array}$ & $\begin{array}{c}\text { Measured } \\
\text { MW }^{\text {e }}(\mathbf{k D a})\end{array}$ & $\begin{array}{l}\text { Hydrodynamic } \\
\text { Radius }{ }^{\text {(nm) }}\end{array}$ \\
\hline SI & MG(VPGSG) $)_{48}(\mathrm{VPGIG})_{48} \mathrm{Y}$ & 25.5 & 73.8 & 39.6 & 39.5 & $23.6 \pm 0.4$ \\
\hline IBP-SI & $\frac{\text { MGFEGFSFLAFEDFVSSIG }}{\left(\frac{\mathrm{VPGSG})_{48}(\mathrm{VPGIG})_{48} \mathrm{Y}}{}\right.}$ & 25.7 & 46.9 & 41.5 & 41.4 & $21.9 \pm 0.6$ \\
\hline
\end{tabular}

${ }^{\mathrm{a}}$ Underlined bold: mouse ICAM-1 targeting peptide identified by phage display screening [25]. ${ }^{\mathrm{b}}$ Critical micelle temperature $(25 \mu \mathrm{M}, \mathrm{pH} 7.4)$ determined by optical density measurements at $350 \mathrm{~nm}$. ${ }^{\mathrm{c}}$ Bulk phase temperature $\left(25 \mu \mathrm{M}, \mathrm{pH}\right.$ 7.4) determined by optical density measurements at $350 \mathrm{~nm} .{ }^{\mathrm{d}}$ Expected MW was calculated using DNASTAR Lasergene Editseq (Madison, WI). ${ }^{\text {e }}$ Observed MW $([\mathrm{M}+\mathrm{H}]+)$ was determined by MALDI-TOF-MS. ${ }^{\mathrm{f}}$ Hydrodynamic radius between $T_{t 1}$ and $T_{t 2}$ in phosphate-buffered saline (PBS; $25 \mu \mathrm{M}, \mathrm{pH} 7.4$ ) was measured by Dynamic Light Scattering (DLS) and is expressed as mean \pm standard deviation (SD) $(n=10)$.

The thermal transition behavior $\left(T_{t 1}\right.$ and $T_{t 2}$ ) of these ELPs was determined using UV-vis spectrophotometry by monitoring the optical density at $350 \mathrm{~nm}$ as a function of temperature in PBS. SI exhibited two steep thermal responses at $25.5{ }^{\circ} \mathrm{C}\left(T_{t 1}\right)$ and $73.8^{\circ} \mathrm{C}\left(T_{t 2}\right)$, conferred by the hydrophobic (Val-Pro-Gly-Ile-Gly) ${ }_{48}$ and the hydrophilic (Val-Pro-Gly-Ser-Gly) ${ }_{48}$ motifs, respectively (Table 1; Figure 2A). In general, guest residues (Xaa) that are more hydrophobic confer a lower transition temperature relative to those that are hydrophilic. The first phase separation at $T_{t 1}$ involves a transition from soluble monomers to supramolecular micelles. Upon heating, nanoparticle assembly causes an abrupt increase in optical density. SI remains a stable nanoparticle between $T_{t 1}$ and $T_{t 2}$, undergoing a bulk phase transition to coacervate when the temperature reaches $T_{t 2}$. Similar to SI, IBP-SI showed two obvious phase transitions at $25.7^{\circ} \mathrm{C}\left(T_{t 1}\right)$ and $46.9^{\circ} \mathrm{C}\left(T_{t 2}\right)$. Both SI and IBP-SI exhibit similar $T_{t 1}$; however, they have distinct $T_{t 2}$. The reduction in $T_{t 2}$ for IBP-SI compared to SI may result from the adhesion between IBP-decorated nanoparticles. The concentration dependence of $T_{t}$ for SI and IBP-SI is log-linear (Figure 2B), in accordance with many other reported ELP fusions $[27,29,30]$. The hydrodynamic radii of SI and IBP-SI were also determined using dynamic light scattering (DLS) at $37^{\circ} \mathrm{C}$. SI and IBP-SI exist as nanoparticles between $T_{t 1}$ and $T_{t 2}$, with radii of $23.6 \pm 0.4 \mathrm{~nm}$ and $21.9 \pm 0.6 \mathrm{~nm}$, respectively (Table 1; Figure 2C). These results suggest that the addition of mouse ICAM-1 binding peptide to SI minimally influences the critical micelle temperature $\left(T_{t 1}\right)$ and particle size of SI at physiological temperatures.

\subsection{IBP-SI Nanoparticles Target ICAM-1 In Vitro}

ICAM-1 transports its ligands to lysosomes via ICAM-1 mediated endocytosis [31]. In endothelial cells, ICAM-1 binding to cargo triggers nonclassical endocytosis and delivery to lysosomes [32]. To determine if IBP-SI can selectively target ICAM- 1 and be internalized through ICAM-1 dependent endocytosis into cells, we used HeLa cells transfected with and expressing fluorescently tagged mouse ICAM-1 as an in vitro model. Confocal fluorescence microscopy was utilized to track the internalization of rhodamine-labeled (rh) materials. The cells were incubated with $30 \mu \mathrm{M}$ of rh-ELPs at $37^{\circ} \mathrm{C}$ for $30 \mathrm{~min}$ and $120 \mathrm{~min}$ before analysis. Cells incubated with rh-SI showed little to no fluorescent signal in the cytoplasm, while cells incubated with rh-IBP-SI showed significant punctate intracellular accumulation, suggesting that IBP-SI was internalized via ICAM-1 mediated endocytosis (Figure 3). 

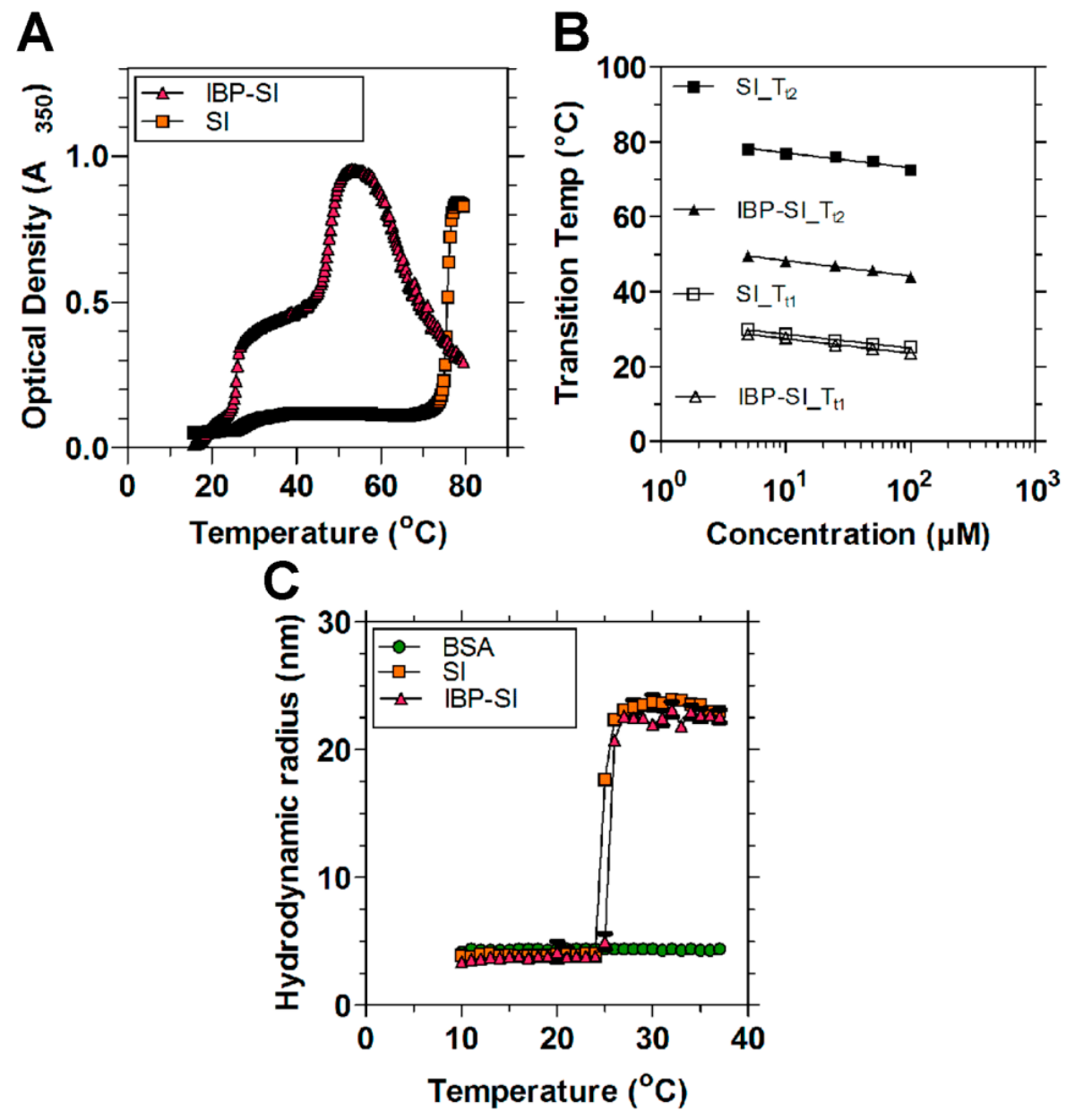

Figure 2. ELP protein-polymers with or without ICAM-1-targeting peptides form nanoparticles at physiological temperature. (A) Temperature-induced assembly of ELPs was determined by measurement of optical density $\left(\mathrm{OD}_{350}\right)$ as a function of temperature and concentration. Both SI and IBP-SI $(25 \mu \mathrm{M}$ in PBS) have two obvious inflections. $T_{t 1}$ is consistent with the assembly of the hydrophobic I48, whereas $T_{t 2}$ is associated with the bulk phase separation of hydrophilic S48. Diblock ELPs assemble into nanoparticles between $T_{t 1}$ and $T_{t 2}$. At this concentration, SI assembles into nanoparticles between $25.5^{\circ} \mathrm{C}$ and $73.7{ }^{\circ} \mathrm{C}$ and IBP-SI assembles nanoparticles between $25.7{ }^{\circ} \mathrm{C}$ and $46.9{ }^{\circ} \mathrm{C}$. (B) The concentration-temperature phase diagrams for SI and IBP-SI follow a log-linear relationship. The $T_{t} s$ of each ELP were fitted to the equation $T_{t}=m \log _{10}\left(C_{E L P}\right)+b$, where $m$ is the slope, $C_{E L P}$ is the concentration, and $b$ is the transition temperature at $1 \mu \mathrm{M}$ (Appendix A Table A1). (C) DLS was used to measure the self-assembly and hydrodynamic radius of ELP nanoparticles ( $25 \mu \mathrm{M}$ in PBS) up to $37^{\circ} \mathrm{C}$. The ICAM-1 binding peptide has minimal influence on the assembly and radius of ELP nanoparticles. Bovine serum albumin (BSA) was used as an internal control. At $37^{\circ} \mathrm{C}$, SI and IBP-SI form nanoparticles with a hydrodynamic radius of $23.6 \pm 0.4 \mathrm{~nm}$ and $21.9 \pm 0.6 \mathrm{~nm}$, respectively. Data are presented as mean \pm SD. 


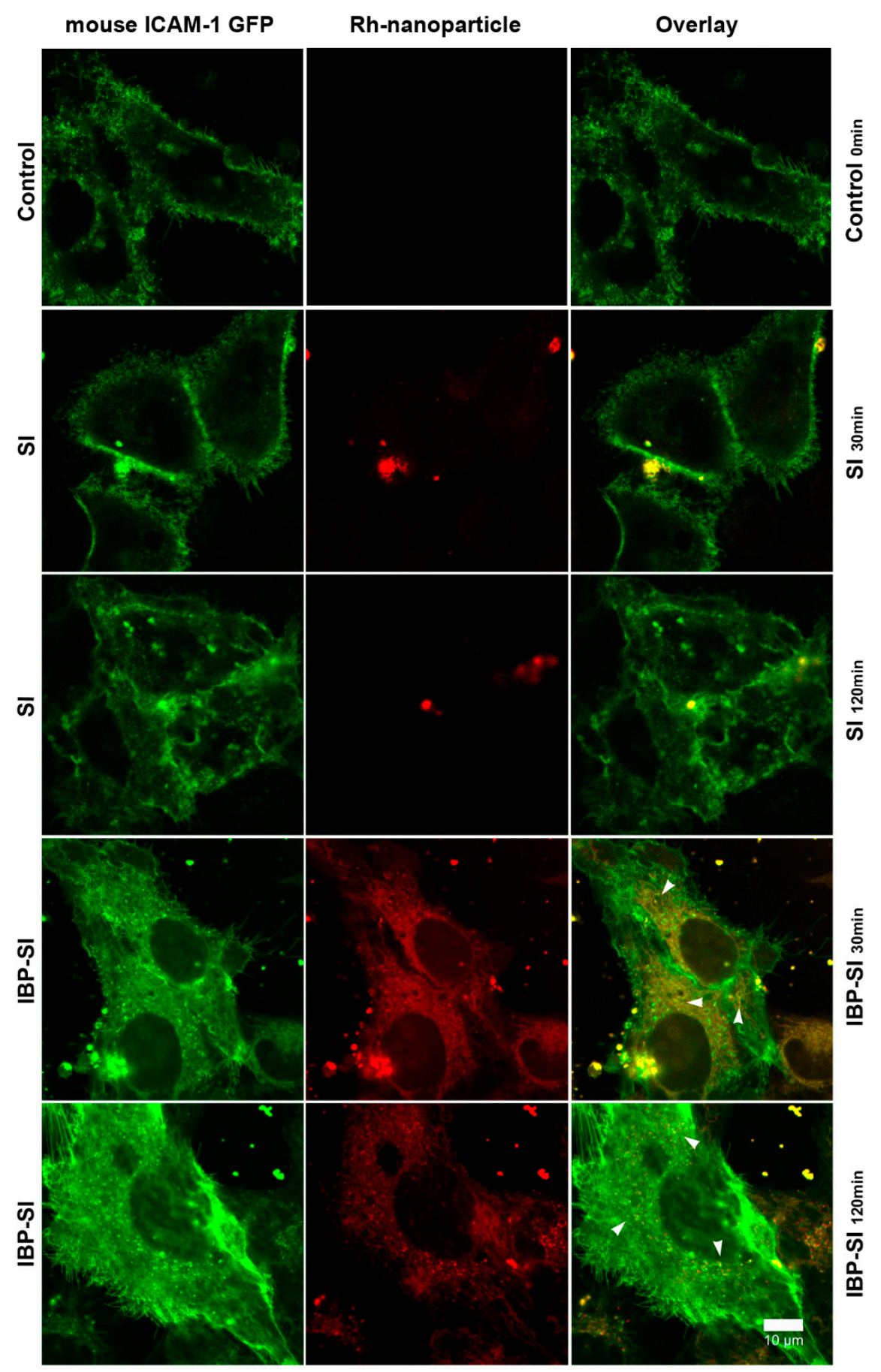

Figure 3. IBP-SI is internalized in HeLa cells expressing mouse ICAM-1. HeLa cells transfected with mICAM-1 GFP were incubated with rhodamine (Rh)-labeled ELPs at $37^{\circ} \mathrm{C}$ for $30 \mathrm{~min}$ or $120 \mathrm{~min}$ prior to imaging using confocal fluorescence microscopy. At comparable time points, IBP-SI-treated cells displayed more accumulation of red puncta within vesicular internal compartments than those incubated with SI. ICAM-1 expressing HeLa cells without ELP treatment was used as a negative control. This experiment was repeated at least twice. Green, mouse ICAM-1 GFP; red, ELP nanoparticles; white arrowheads, internalized ELP nanoparticles. Scale bar $=10 \mu \mathrm{m}$.

Cross-species reactivity of IBP-SI against human ICAM-1 was also seen. In Appendix A Figure A2, non-transfected HeLa cells incubated with rh-IBP-SI showed accumulation of red puncta as the incubation period increased, relative to those incubated with rh-SI. HeLa cells pretreated with anti-human ICAM-1 antibody exhibited decreased surface binding and uptake of IBP-SI compared to 
untreated cells (Appendix A Figure A3). These data collectively suggest that IBP-SI is recognized and internalized both by mouse and human ICAM-1 (Figures 3, A2 and A3).

Having demonstrated the cross-species ability of IBP-SI to be internalized more efficiently than SI in cells expressing mouse or human ICAM-1, its intracellular trafficking was assessed utilizing a pulse-chase approach. mICAM-1 transfected HeLa cells were co-transduced with baculoviruses encoding either Rab5a-, Lamp1-, or Golgi-red fluorescent protein (RFP) (red) to mark early endosomes, lysosomes, and Golgi, respectively. IBP-SI was labeled with Cy5 and incubated with cells for $15 \mathrm{~min}$ at a concentration of $30 \mu \mathrm{M}$ before live cell confocal fluorescence microscopy imaging for another $45 \mathrm{~min}$. This analysis revealed that some IBP-SI was co-localized with Rab5-enriched early endosomes after 15 min incubation (Figure 4A). The fluorescent signal of IBP-SI was increasingly observed in lysosomes throughout the entire chase period (Figure 4B) but not in the Golgi (Figure 4C). In addition, analysis by confocal microscopy imaging used to analyze ICAM-1 expressing HeLa cells $3 \mathrm{~h}$ after the $1 \mathrm{~h}$ chase with Cy5-IBP-SI showed that Cy5-IBP-SI resided almost exclusively in lysosomes (Figure 4D). These findings collectively suggest that IBP -SI bound to ICAM-1 is first sorted into early endosomes and then a fraction of this endocytosed material accumulates in lysosomes. These findings further suggest that IBP-SI binding triggers internalization of ICAM-1, which has the potential to reduce tissue signals for lymphocyte homing.

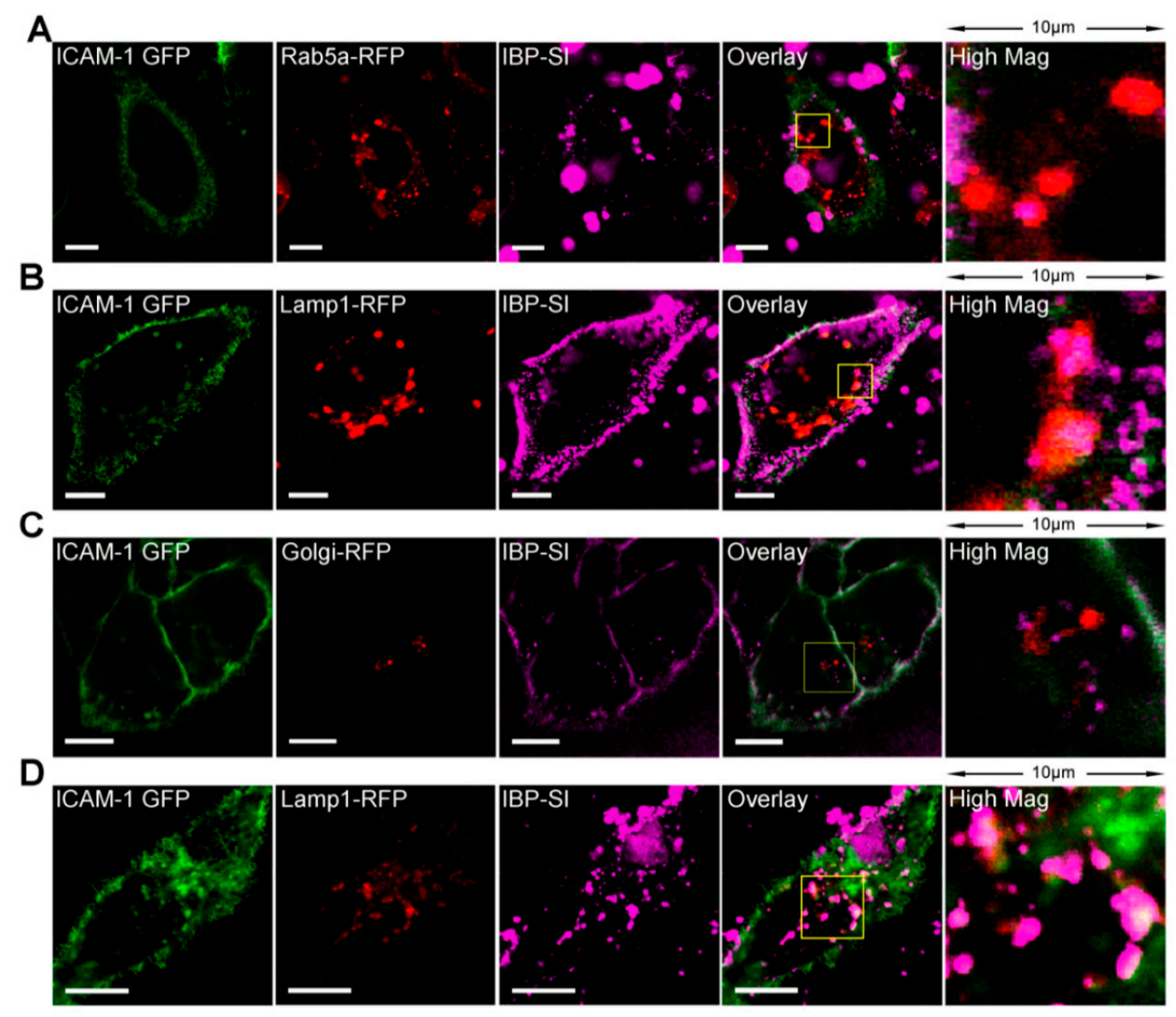

Figure 4. IBP-SI nanoparticles traffic to early endosomes and lysosomes. mICAM-1 expressing HeLa cells transduced with CellLight ${ }^{\circledR}$ (A) Rab5-RFP, (B) Lamp1-RFP, and (C) Golgi-RFP Bacmam 2.0 reagents were pulsed with $30 \mu \mathrm{M}$ Cy5-labeled IBP-SI for $10 \mathrm{~min}$, with a 45-min chase period prior to imaging. IBP-SI showed apparent regions of co-localization with Rab5-RFP (Panel A, Overlay) and extensive apparent colocalization with Lamp1-RFP (Panel B, Overlay) but was not colocalized with Golgi-RFP (Panel C, Overlay), suggestive of its routing through early endosomes to lysosomes. (D) IBP-SI exhibits high co-localization with Lamp1-RFP (Panel D, Overlay) after $3 \mathrm{~h}$ of incubation. This experiment was repeated at least twice. Scale bar $=10 \mu \mathrm{m}$. 


\subsection{ICAM-1 Is Significantly Overexpressed in the LG of NOD Mice Compared with Healthy Mice}

Male NOD mice have been reported to fully develop the autoimmune dacryoadenitis characteristic of SS, manifested as a significant lymphocytic infiltration in the LG by 12 weeks of age [33]. A previous analysis of ICAM-1 gene and protein expression showed that ICAM-1 is increased by 3.5-fold in NOD mouse LG [20]. ICAM is also overexpressed in the LG of lymphoproliferative, MRL-lpr mice, another mouse model of SS [19]. LG are comprised of $85 \%$ by mass LG acinar cells (LGACs; polarized epithelial cells responsible for transport, production and secretion of tear proteins), as well as vasculature, ductal epithelium, and lymphocytes. Immunofluorescence was used to determine the distribution of ICAM-1 protein in these cell types in BALB/c and NOD LG. Lymphoid foci are detected in NOD LGs but not BALB/c LGs, and ICAM-1 was enriched in these foci (Figure 5A). Higher magnification images revealed that ICAM-1 was overexpressed in basolateral membranes of LGACs from NOD mice, vasculature, and individual lymphocytes. ICAM-1 could be also be detected on sparsely distributed cells in BALB/c LGs (Figure 5B).

A ICAM-1
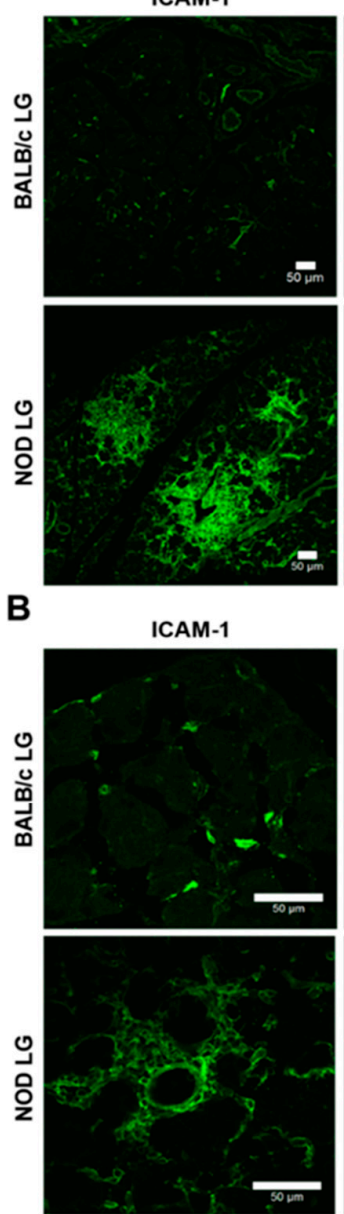

F-actin
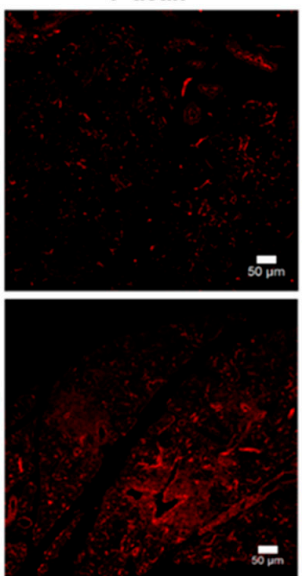

F-actin
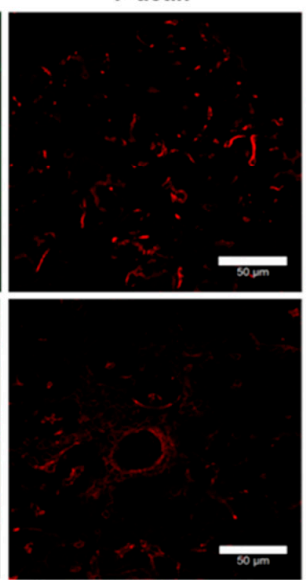

Nucleus

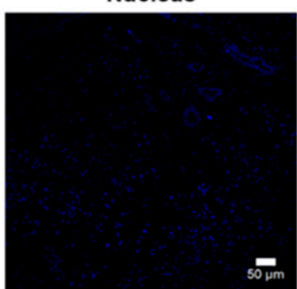

spm

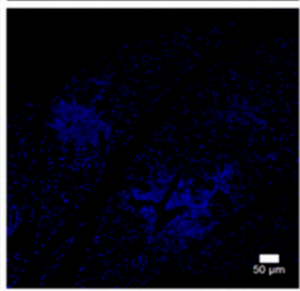

Nucleus

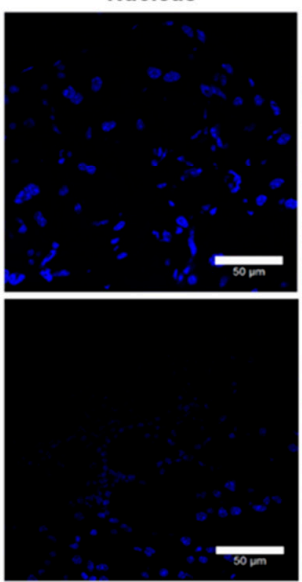

Overlay

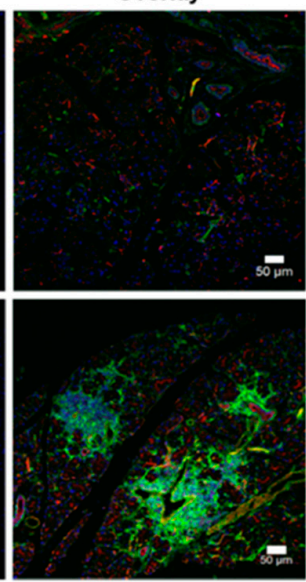

Overlay

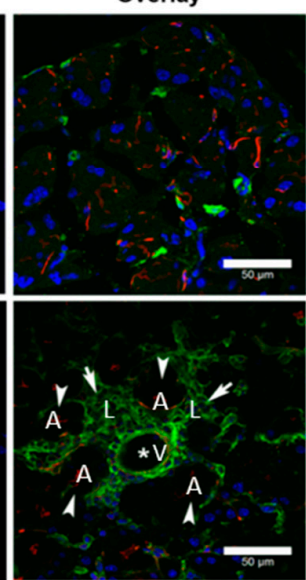

Figure 5. Distribution of mICAM-1 in lacrimal glands (LGs) of BALB/c and NOD mice. Cryosections of LGs from 12-week-old male BALB/c and NOD mice were processed and imaged at low and high magnification using confocal microscopy. mICAM-1 was labeled with goat anti-mouse ICAM-1 primary antibody and AF-488 conjugated donkey anti-goat secondary antibody (green). F-actin was labeled with rhodamine phalloidin (red) and nuclei were labeled with $4^{\prime}$,6-diamidino-2-phenylindole (DAPI) (blue). (A) mICAM-1 expression is detected in lymphocytic infiltrates of the LG and correlated with the severity of the inflammation. (B) mICAM-1 expression was also observed in vascular endothelium, lymphocytes, and basolateral membranes of LG epithelial cells next to lymphocytes. White arrowheads (A): LG acini; white arrows (L): lymphocytes; * (V): vascular lumen. 
Consistent with the increased expression of ICAM-1 in the LGACs of NOD mice, internalization of IBP-SI, but not SI, was also observed when ex vivo cultured primary LGACs from NOD mice were incubated with rh-IBP-SI and rh-SI (Appendix A Figure A4).

\subsection{Inhibition of Lymphocyte Binding to ICAM-1 Enriched bEnd.3 Cells by IBP-SI}

The lymphocyte function-associated antigen-1/intercellular adhesion molecule-1 (LFA-1/ICAM-1) interaction plays an important role in lymphocytic adhesion and trans-vessel migration. The induction of ICAM-1 in LG in NOD mice with autoimmune dacryoadenitis seen in Figure 5 is likely involved in homing of immune cells into the LG associated with autoimmune inflammation. To assess whether IBP-SI disrupts the interaction between these two receptors, bEnd. 3 cells were induced with TNF- $\alpha$ to express high levels of mICAM- 1 as a source of ICAM-1, and mouse splenocytes were stained with Carboxyfluorescein succinimidyl ester (CFSE) as a source of LFA-1 enriched cells. Their interactions were probed using an in vitro assay. Briefly, splenocytes were stimulated with Phorbol 12-myristate 13-acetate (PMA) to activate LFA-1 before incubation with bEnd.3 cells [34,35]. IBP-SI at various concentrations was incubated with splenocytes and then added to wells containing confluent bEnd.3 cells induced to express mICAM-1. SI was used as a control for non-specific effects of the ELP nanoparticle, as it was not expected to bind to mICAM-1. A concentration-dependent inhibition of splenocyte adherence was observed in the flow cytometry assay for IBP-SI, with an $\mathrm{IC}_{50}$ of $62.7 \mu \mathrm{M}$ IBP-SI (Figure 6A), while the plate reader assay showed that IBP-SI also inhibited splenocyte adherence with an IC I0 $_{5}$ of $81.2 \mu \mathrm{M}$ (Figure $6 \mathrm{~B}$ ). Using $100 \mu \mathrm{M}$ concentrations of IBP-SI and SI, which slightly exceed the $\mathrm{IC}_{50}$, IBP-SI significantly inhibited splenocyte binding to an average of $47.1 \%(p=0.017)$. As a negative control, SI showed little reduction of splenocyte binding at $86.9 \%$ (Figure 6C) as determined by flow cytometry. Similarly, we observed that IBP-SI significantly inhibited the adhesion of fluorescently labeled splenocytes to an average of $8.3 \%$, while SI showed minimal reduction at $76.2 \%(p=0.003)$ (Figure 6D). This further demonstrates the ability of IBP-SI to specifically target ICAM-1 expressing cells while dually disrupting splenocyte adherence.
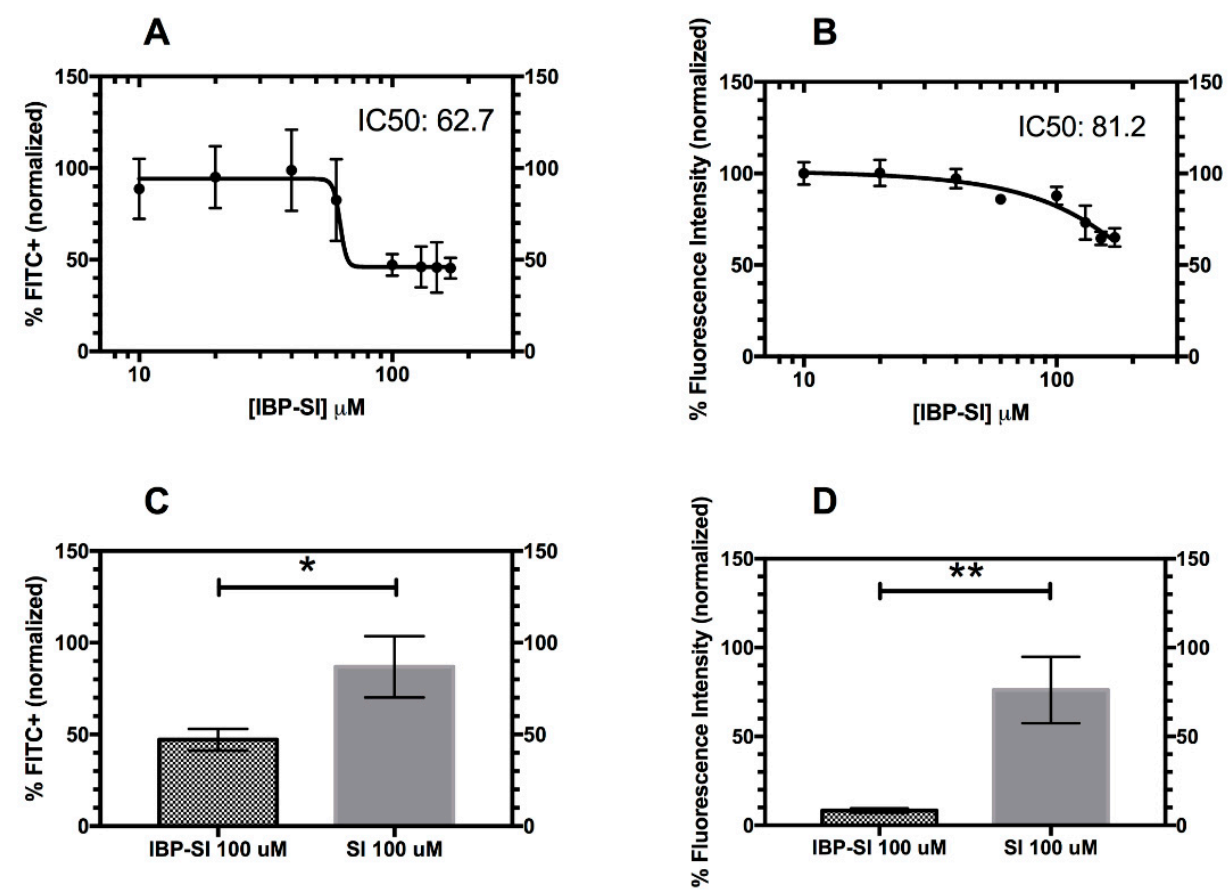

Figure 6. IBP-SI significantly inhibits the binding of splenocytes to ICAM-1 overexpressing endothelial cells. IBP-SI shows concentration-dependent inhibition of Phorbol 12-myristate 13-acetate (PMA)-induced splenocyte binding to ICAM-1-overexpressing bEnd.3 cells at $37^{\circ} \mathrm{C}$, as assessed by detection of Carboxyfluorescein succinimidyl ester (CFSE)-labeled splenocyte fluorescence by flow cytometry 
$(A, C)$ and a fluorescence plate reader (B,D). (A) The $\mathrm{IC}_{50}$ of IBP-SI calculated using flow cytometry. The amount of splenocytes adhering to bEnd.3 cells was measured by flow cytometry and normalized to splenocyte binding to cells in the absence of added ELP, which was defined as $100 \%$. (B) The $\mathrm{IC}_{50}$ of IBP-SI was identified by a plate reader assay. (C) PMA-induced splenocytes, labelled with CFSE, were incubated with a Tumor Necrosis Factor (TNF)- $\alpha$ stimulated bEnd.3 monolayer, with a confluency above $80 \%$, in the presence of $100 \mu \mathrm{M}$ IBP-SI or SI for $45 \mathrm{~min}$ at $37^{\circ} \mathrm{C}$. (D) PMA-induced splenocytes were incubated with a TNF- $\alpha$ stimulated bEnd. 3 monolayer, at a confluency above $80 \%$, in the presence of $100 \mu \mathrm{M}$ IBP-SI or SI for $45 \mathrm{~min}$ at $37^{\circ} \mathrm{C}$. Adhesion was confirmed by retention of fluorescence in a plate-based assay. The percentage of fluorescence intensity relative to no-ELP treatment control, defined as $100 \%$, is plotted under each condition (Equation (1)). Each treatment was performed in triplicate wells three times and plotted as the overall mean \pm SD for (A-D). An IBP-SI and SI concentration above the $\mathrm{IC}_{50}$ was used to observe maximal inhibition for (C) and (D). ${ }^{*} p<0.05,{ }^{* *} p<0.01$.

\subsection{IBP-SI Inhibits the Activation and Proliferation of T-Cells}

The ICAM-1/LFA-1 interaction not only plays an important role in leukocyte adhesion and migration, but also acts as an important co-stimulatory factor for T-cell activation by antigen presenting cells [36,37]. Interfering with the LFA-1/ICAM-1 interaction can impair T-cell activation, proliferation and differentiation [38], which is not mitigated by boosting the interaction between T-Cell Receptor (TCR) and Major Histocompatibility Complex MHC complexes [39]. Therapies targeting the ICAM-1/LFA-1 interaction have been shown to have positive effects in several eye diseases such as dry eye disease and allergic conjunctivitis [40,41]. Here, we tested whether IBP-SI can inhibit the activation and proliferation of T-cells through its ability to disrupt the ICAM-1/LFA-1 interaction. CH27 cells are a mouse B-cell line widely used as an antigen presenting cell line. $\mathrm{CH} 27$ cells can stimulate the activation and proliferation of T-cells in the presence of the moth cytochrome C (MCC) antigenic peptide [42,43]. We found that proliferation of T-cells isolated from the mouse spleen and stimulated with MCC-loaded CH27 cells was inhibited by IBP-SI to $26.1 \pm 18.7 \%(p=0.01)$ of that seen in the untreated mixture, whereas no significant inhibition $(91.2 \pm 13.9 \%)$ was observed with SI (Figure 7).

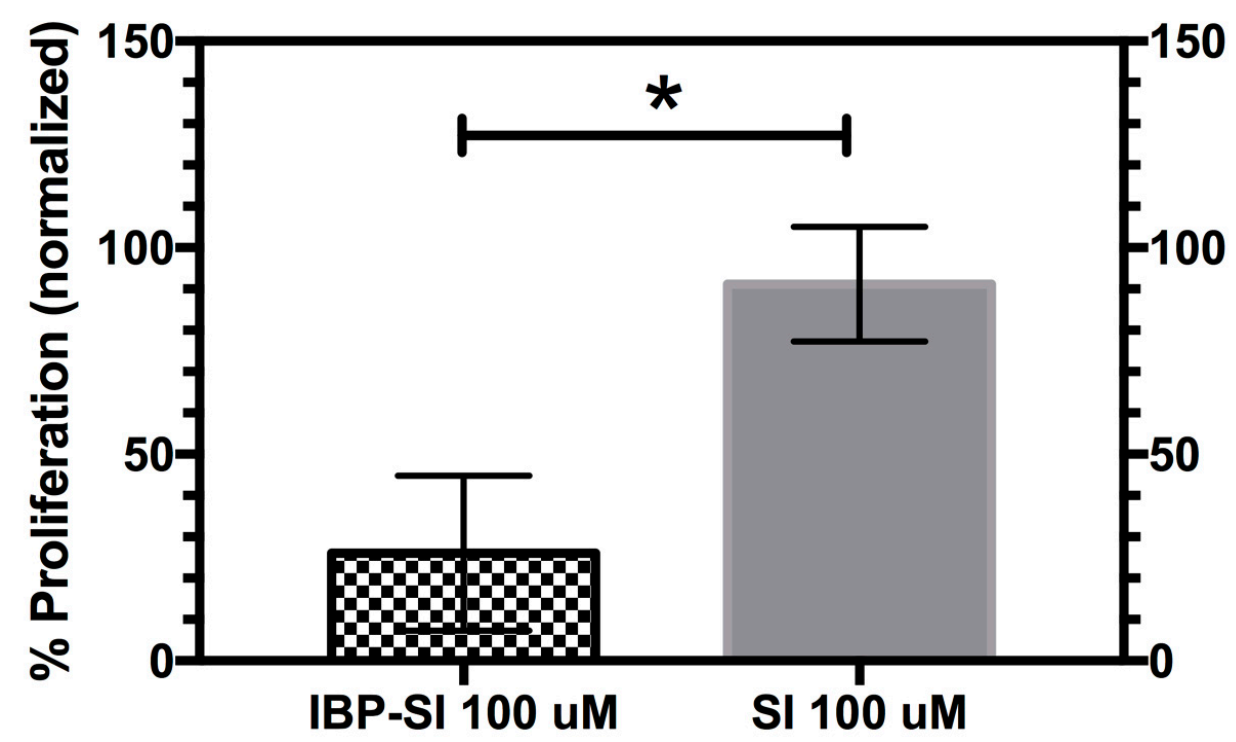

Figure 7. IBP-SI significantly reduces the proliferation of CD4+ T-cells relative to SI. CH27 cells treated with $15 \mu \mathrm{M}$ moth cytochrome $\mathrm{c}$ (MCC) antigenic peptide were incubated with CFSE-labelled CD4+ T-cells in the presence of $100 \mu \mathrm{M}$ IBP-SI or SI. After 5 days of incubation, FITC+ cells were analyzed by flow cytometry and the results were fitted into a proliferation model with FlowJo (v10.6.2). The percentage of proliferation compared to generation 0 calculated from the fitting model for the IBP-SI and SI-treated groups was plotted after normalization to that from non-ELP treated controls. Each treatment was done in triplicate wells, and the same experiments were repeated three times. Data is plotted as mean $\pm \mathrm{SD} .{ }^{*} p<0.05$ 


\section{Discussion}

This manuscript evaluates a multivalent ICAM-1 antagonist nanoparticle, IBP-SI, which is internalized in ICAM-1 expressing cells, inhibits the adhesion of leukocytes to endothelial cells, and inhibits T-cell activation and proliferation in vitro. This multivalent nanoparticle represents a new tool for probing ICAM-1/LFA-1 interactions in vitro. The mICAM-1 specific peptide used in this study was identified by screening a phage displayed peptide library, which is also multivalent, against mICAM-1 transfected COS-7 cells. It retained the highest avidity for domain-1 of mICAM-1 and was reported to block LFA-1 interactions during antigen presentation [25]. Several ICAM-1 affinity peptides, mostly generated by phage display techniques, and ICAM- 1 targeting nanocarriers have been developed in the past to block leukocyte-endothelial adhesion or intercellular adhesion of immune cells during antigen presentation in vitro and in vivo [44,45]. Some of these have shown an interspecies targeting ability for two or more species. Our work demonstrates that the IBP peptide sequence has cross-species reactivity in mouse and human ICAM-1.

Multiple groups have taken diverse approaches to targeting therapeutic particles using ICAM-1 as a molecular marker and/or to simply target ICAM-1 to inhibit its molecular interactions in driving inflammatory responses. The Muro and Muzykantov groups have used targeted therapeutics to endothelial ICAM-1 in vitro and in vivo for treatment of lysosomal storage diseases, acute and chronic respiratory diseases, and other vascular diseases [32,46-48]. Zhang et al. have developed a cyclic LABL(cLABL)-conjugated Poly Lactic-co-Glycolic Acid (PLGA) nanoparticle approximately $244 \mathrm{~nm}$ in diameter which binds both human epithelial and endothelial ICAM-1 [45,49]. cLABL is a cyclo $(1,12)$ PenITDGEATDSGC peptide derived from the $\alpha_{\mathrm{L}}$-integrin I domain of LFA-1 which blocks T-cell adhesion and reduces lymphocytic infiltration in islet endothelium [50]. By electrostatic adsorption of targeting antibodies onto the surface, polystyrene latex microspheres with particle sizes ranging from $100 \mathrm{~nm}$ to $300 \mathrm{~nm}$ in diameter were selectively delivered to mouse or human ICAM-1 or to other adhesion molecules. Of note, a 17-mer linear peptide derived from the ICAM-1-binding sequence of fibrinogen [44] that shares high sequence homology across human, mouse, and chimpanzees can, when adsorbed to polystyrene nanoparticles, selectively target both human and mouse ICAM-1 similarly to IBP-SI.

Multiple antagonizing peptides have been developed to disrupt the interaction between ICAM-1 and LFA-1. Short peptides derived from the LFA-1 binding domain on ICAM-1 or the ICAM-1 binding domain on LFA-1 showed 23-52\% inhibition of LFA-1/ICAM-1-dependent intercellular adhesion at $250 \mu \mathrm{M}$. Those peptides also inhibited lymphocyte proliferation in a mixed cell reaction by around $60 \%$ at $600 \mu \mathrm{M}$ [51,52]. Another ICAM-1 antagonizing peptide discovered by phage display (LLRMRSIC) showed inhibition of ICAM-1 mediates the adhesion of neutrophils to endothelial cells at a concentration of $2 \mathrm{mM}$ [53]. In comparison, IBP-SI inhibits ICAM-1 mediated cellular adhesion with $\mathrm{IC}_{50}$ around $70 \mu \mathrm{M}$ and inhibits the proliferation of T-cells by around $70 \%$ at $100 \mu \mathrm{M}$. This is a significant improvement compared to other reported peptides.

Xiidra ${ }^{\circledR}$ (5\% Lifitegrast ophthalmic solution), which inhibits the LFA-1/ICAM-1 interaction by targeting the I-domain of LFA-1, was approved in 2016 as a treatment for dry eye disease. In phase II and III clinical trials, dry eye patients treated with Lifitegrast showed significant improvement in clinical symptoms and ocular surface health when compared with patients that received the placebo $[54,55]$. This suggests that other strategies for the inhibition of ICAM-1/LFA-1 interactions, including the eventual in vivo use of IBP-SI, could also be effective strategies for the treatment of dry eye disease. It is notable that this same SI nanoparticle backbone has already been used as a rapamycin drug carrier with therapeutic efficacy in a murine model of SS [7].

IBP-SI has several unique features compared to other ICAM-1 targeted nanoparticles $[45,47,56]$. The protein sequence and size of ELPs can be tuned precisely through genetic engineering of recombinant plasmid in a way that is not achievable by synthetic polymers. ELPs are also characterized by high biocompatibility and biodegradability and low immunogenicity, permitting their safe breakdown into peptides and amino acids that are easily cleared from the body [57]. The major limitations of 
antibody-targeted therapeutics has been their immunogenicity induced from the Fragment crystallizable regions ( $\mathrm{F}_{\mathrm{c}}$ regions) of IgGs [58] as well as the non-specific uptake of antibodies by the reticuloendothelial system [59]. It is widely believed that short peptides with sequences less than 20 amino acids in length should be less immunogenic relative to native proteins [60]. Hence, conjugating a 16-mer ICAM-1 targeted peptide to SI may be expected to arouse minimal host immune responses after long-term in vivo treatment with this ELP nanoparticle.

In summary, IBP-SI constitutes a unique new tool which may be utilized in vitro to probe the role of ICAM-1/LFA-1 interactions in physiological or pathophysiological processes. As a genetically encoded protein polymer constructed on the ELP backbone, its ease of production, biocompatibility and lack of immunogenicity may offer advantages relative to alternative ICAM-1 targeting strategies moving into in vivo studies. The investigation of its therapeutic potential utilizing local and systemic administration for autoimmune dacryoadenitis in SS will be an important next step.

\section{Materials and Methods}

\subsection{Materials and Reagents}

NHS-rhodamine was from Thermo Fisher Scientific (Rockford, IL, USA). Sulfo-Cy5 NHS ester was from Lumiprobe Corp. (Hallandale Beach, FL, USA). Alexa Fluor ${ }^{\circledR} 488$ donkey anti-goat IgG, DAPI (4', 6 -diamidino-2-phenylindole dihydrochloride), rhodamine-phalloidin, CellLight ${ }^{\circledR}$ RFP-Rab5a, RFP-Lamp1, and RFP-Golgi BacMam2.0 reagents were from Life Technologies (Grand Island, NY). HeLa and bEnd. 3 cells were from American Type Culture Collection (ATCC) (Manassas, VA, USA). The $\mathrm{CH} 27$ cell line was a kind gift from Jianming Xie (University of Southern California Manassas). The plasmid expressing mouse ICAM-1 GFP was from Origene (Rockville, MD, USA). Mouse ICAM-1 (mICAM-1) polyclonal antibody was from R\&D Systems (Minneapolis, MN, USA). Glass-bottomed dishes ( $35 \mathrm{~mm}$ ) were from MatTek Corp. (Ashland, MA, USA). The 5-and 6-carboxyfluorescein diacetate succinimidyl ester kit (CFSE), Alexa Fluor ${ }^{\circledR} 700$ anti-mouse CD3 antibody and MojoSort ${ }^{\mathrm{TM}}$ CD4+ T-cell isolation kits were from Biolegend (San Diego, CA, USA). Recombinant mouse TNF- $\alpha$ was from Abcam (Cambridge, UK). Moth cytochrome C (83-103) was from GenScript (Piscataway, NJ, USA). Other reagents were from standard suppliers.

\subsection{Animals}

$\mathrm{BALB} / \mathrm{c}, \mathrm{C} 57 \mathrm{BL} / 6 \mathrm{~J}$ and NOD (SS disease model) breeding pairs were purchased from Charles River Laboratories (Wilmington, MA, USA), The Jackson Laboratory (Bar Harbor, ME, USA) and Taconic Farms (Hudson, NY, USA), respectively. Animals were bred in the University of Southern California (USC) vivarium. All animal procedures were approved by the USC Institutional Animal Care and Use Committee under protocols 11788 (first approved for these studies Jan 2012) and 10547 (first approved for these studies Nov 2008), both protocols have been revised and renewed yearly after that. All procedures were performed in accordance to the Guide for Care and Use of Laboratory Animals, 8th edition [61]. For analysis of LG in BALB/c and NOD mice, all mice used in this study were males, aged 12-14 weeks. For immunofluorescence labeling of ICAM-1, LGs were removed after mice were euthanized via intraperitoneal injection with $55 \mathrm{mg}$ ketamine and $14 \mathrm{mg}$ zylazine per kilogram of body weight, followed by cervical dislocation. For isolation of splenocytes, the spleens from female C57BL/6J mice were removed after the mice were euthanized as described above.

\subsection{Construction of IBP-SI ELP Nanoparticles}

The plasmid pET25b(+) encoding the ELP diblock copolymer, SI, was synthesized using plasmid recursive directional ligation as described previously [62]. Sense and antisense murine ICAM-1 specific peptide sequences, identified by phage display selection [25], were synthesized with NdeI (5') and BamHI ( $\left.3^{\prime}\right)$ overhangs (Integrated DNA Technologies Inc., Coralville, IA): sense (5'-TATGGGTTTCGAAGGCTTCTCGTTCCTCGCATTCGAAGACTTCGTATCATCAATAGGTTA 
CTGATCTCCTCGG-3') and antisense (5'-GATCCCGAGGAGATCAGTAACCTATTGATGATACGA AGTCTTCGAATGCGAGGAACGAGAAGCCTTCGAAACCCA-3'). Complementary oligonucleotides were heated at $95^{\circ} \mathrm{C}$ for $2 \mathrm{~min}$ and cooled to room temperature for $3 \mathrm{~h}$. The annealed oligonucleotides were ligated into the $\mathrm{pET} 25 \mathrm{~b}(+)$ vector, previously digested with NdeI and BamHI. The SI gene was then ligated downstream of the murine ICAM-1 specific sequence using BseRI and BssHII cutting sites in both plasmids. The correct ligation clones were confirmed by DNA diagnostic digestion and DNA sequencing. ELPs were expressed in the BLR (DE3) E. coli strain and purified by induction of the ELP-mediated phase separation. The purity of ELP fusion proteins was determined by running $50 \mu \mathrm{g}$ of samples on a $4-20 \%$ SDS-PAGE gel stained with $10 \%(w / v)$ copper chloride. Protein concentrations were determined by measuring the absorbance of protein polymers at $280 \mathrm{~nm}$ and calculated using the Beer-Lambert law $\left(\varepsilon_{\mathrm{SI} / \mathrm{IBP}-\mathrm{SI}}=1285 \mathrm{M}^{-1} \mathrm{~cm}^{-1}\right)$. Protein molecular mass was further confirmed by MALDI-TOF mass spectrometry (AXIMA Assurance, Shimadzu, Kyoto, Japan).

\subsection{Characterization of IBP-SI Phase Transition Behavior and Nanoparticle Formation}

The temperature-concentration phase diagram of IBP-SI ELP was determined by optical density measurements at $350 \mathrm{~nm}$ using a DU800 UV-vis spectrophotometer (Beckman Coulter, Brea, CA, USA). $T_{t}$ was defined as the temperature point showing 50\% maximal turbidity. Self-assembly and hydrodynamic radius $\left(R_{h}\right)$ of ELP nanoparticles was measured using DLS in a DynaPro-LSR Plate Reader (Wyatt Technology, Santa Barbara, CA, USA). For DLS measurements, samples were prepared at $25 \mu \mathrm{M}$ in PBS and filtered through a filter with a $0.02 \mu \mathrm{m}$ pore size at $4{ }^{\circ} \mathrm{C}$. Each sample $(90 \mu \mathrm{L})$ was applied to a pre-chilled 384 well microplate, centrifuged at $4{ }^{\circ} \mathrm{C}$ to remove air bubbles, and covered with $20 \mu \mathrm{L}$ of mineral oil to prevent evaporation. DLS data were recorded at regular temperature intervals $\left(1{ }^{\circ} \mathrm{C}\right)$ as solutions were heated from $10^{\circ} \mathrm{C}$ to $37^{\circ} \mathrm{C}$. The results were fitted to a cumulant algorithm based on the sum-of-squares value and analyzed with a Rayleigh sphere model. $T_{t 1}$, the critical micelle temperature, was defined as the lowest temperature at which the $R_{h}$ is significantly greater than the averaged monomer $R_{h}$.

\subsection{Fluorescent Labelling of ELP Nanoparticles}

For fluorescent visualization, SI and IBP-SI ELPs were conjugated with NHS-rhodamine ester or Sulfo-Cy5 NHS ester via the chemical covalent crosslinking of the fluorophore to the lysine at the $\mathrm{N}$-terminus of ELP polypeptides. Conjugation reactions were performed in $100 \mathrm{mM}$ borate buffer (pH 8.5) at $4{ }^{\circ} \mathrm{C}$ overnight. Excess fluorophore was removed by size exclusion chromatography on a pre-packed G-25 desalting column (GE Healthcare, Piscataway, NJ, USA).

\subsection{In Vitro Cell Uptake}

HeLa cells were grown in a $35 \mathrm{~mm}$ glass-bottomed plate until at $90 \%$ confluence or greater. Transfection of mICAM-1 GFP by Lipofectamine $2000^{\circledR}$ was performed according to the manufacturer's recommendation. Briefly, cells were treated with a mixture of mICAM-1 GFP plasmid $(\mu \mathrm{g})$ and Lipofectamine $2000^{\circledR}(\mu \mathrm{L})$ at a ratio of $1: 2$ at $37^{\circ} \mathrm{C}$ for $6 \mathrm{~h}$ followed by a wash with PBS, and maintained in complete medium at $37^{\circ} \mathrm{C}$ for another $36-48 \mathrm{~h}$ prior to uptake and intracellular trafficking experiments. For uptake studies, mICAM- 1 expressing HeLa cells were incubated with $30 \mu \mathrm{M}$ of rhodamine-labelled (rh)-SI or -IBP-SI at $37^{\circ} \mathrm{C}$ for $30 \mathrm{~min}$ and $120 \mathrm{~min}$. Cells were then rinsed with warm PBS three times, maintained in fresh culture medium, and imaged by confocal fluorescence microscopy. To follow the intracellular trafficking of internalized IBP-SI, mICAM-1-expressing HeLa cells were transduced with recombinant baculovirus expressing RFP-Rab5a, RFP-Lamp-1, or RFP-Golgi. After $16-18 \mathrm{~h}$ of transduction, cells were incubated with $30 \mu \mathrm{M}$ of Cy5-IBP-SI at $37^{\circ} \mathrm{C}$ for $10 \mathrm{~min}$, rinsed with warm PBS three times, and imaged for another $45 \mathrm{~min}$. Images were acquired using a Zeiss laser scanning microscope 510 Meta NLO or an LSM 800 confocal imaging system (Carl Zeiss, Thornwood, NY, USA). 


\subsection{Immunofluorescence of Mouse LG}

Immunofluorescence labeling of mouse LG was performed as previously described [20]. Briefly, LGs from NOD and BALB/c mice were fixed, embedded and cut into $5 \mu \mathrm{m}$ sections. For immunofluorescence labeling, $\mathrm{LG}$ sections were quenched with $50 \mathrm{mM} \mathrm{NH}_{4} \mathrm{Cl}$, permeabilized with $0.1 \% \mathrm{~T} x-100$, and blocked with $1 \%$ bovine serum albumin (BSA). The resulting slides were then incubated with goat-anti mICAM-1 primary antibody at $4{ }^{\circ} \mathrm{C}$ overnight followed by incubation with donkey-derived Alexa Fluor 488-conjugated anti-goat IgG secondary antibody at $37^{\circ} \mathrm{C}$ for $1 \mathrm{~h}$ before analysis by confocal microscopy.

\subsection{Splenocyte Isolation, Labelling and Quantitation}

Freshly isolated spleens from C57BL/6 female mice were homogenized by pressing the tissue through a $70 \mu \mathrm{m}$ filter into a $50 \mathrm{~mL}$ conical tube while washing with red blood cell lysing buffer $\left(0.15 \mathrm{M} \mathrm{NH}_{4} \mathrm{Cl}, 1 \mathrm{mM} \mathrm{NaHCO} 3,0.1 \mathrm{mM}\right.$ Ethylenediaminetetraacetic acid EDTA). The remaining cell suspension was spun down at $437 \times g$ for $10 \mathrm{~min}$, resuspended in PBS and counted using a TC20 automated cell counter (Bio-Rad Laboratories, Inc. Hercules, CA). Splenocytes were labelled with $2 \mu \mathrm{M}$ CFSE and incubated at $37^{\circ} \mathrm{C}$ for $20 \mathrm{~min}$, away from light. The remaining free label was then quenched with $5 \mathrm{~mL}$ of bEnd. 3 culture media, in accordance with the manufacturer's guidelines. Splenocytes were treated with PMA at $10 \mathrm{ng} / \mathrm{mL}$ for $30 \mathrm{~min}$ to induce activation of LFA-1 on cell surfaces prior to incubation with bEnd.3 cells [20].

\subsection{In Vitro Static Adhesion Assay}

bEnd. 3 cells were cultured in Dulbecco's Modified Eagle's Medium (DMEM), 10\% fetal bovine serum, $1 \times$ penicillin/streptomycin and $2 \mathrm{mM} \mathrm{L-glutamine}$ at $37^{\circ} \mathrm{C}$ in a $5 \% \mathrm{CO}_{2}$ incubator. bEnd.3 cells were incubated with mouse TNF- $\alpha$ at $10 \mathrm{ng} / \mathrm{mL}$ overnight the day before the assay to induce ICAM-1 expression. IBI-SI, at concentrations from 10 to $150 \mu \mathrm{M}$, or SI at $100 \mu \mathrm{M}$ were diluted into adhesion solution (PBS containing 0.5\% BSA, $2 \mathrm{mM} \mathrm{MgCl}_{2}$ and $1 \mathrm{mM} \mathrm{CaCl}_{2}$ ) and incubated with $1 \times 10^{6}$ CFSE-labelled splenocytes, and then added to TNF- $\alpha$ induced bEnd. 3 cells grown on clear 24-well flat bottom tissue culture plates at $37^{\circ} \mathrm{C} 5 \% \mathrm{CO}_{2}$ for $45 \mathrm{~min}$. Non-adherent cells were aspirated gently and each well was washed twice with $250 \mu \mathrm{L}$ of wash solution (PBS with $2 \mathrm{mM} \mathrm{MgCl}_{2}$ and $1 \mathrm{mM} \mathrm{CaCl} 2$ ). Adherent cells were then trypsinized, pelleted by centrifugation, and resuspended in Fluorescence-activated cell sorting FACS buffer (PBS with 0.5\% BSA and $1 \mathrm{mM}$ EDTA) prior to analysis on an LSR2 flow cytometer (BD Biosciences). Data were analyzed using FlowJo software and the percentage of fluorescent splenocytes associated with ICAM-1-overexpressing bEnd. 3 cells under each treatment condition was expressed as a percentage of non-ELP-treated splenocytes binding to cells, defined as $100 \%$. Similarly, IBP-SI and SI effects on ICAM-1 overexpressing bEnd.3 cells and PMA-induced CFSE-labelled splenocyte binding were assessed using a plate assay. Briefly, bEnd.3 cells seeded in a 96-well flat black bottom plate were stimulated with TNF- $\alpha$ as above. IBP-SI at varying concentrations $(10-150 \mu \mathrm{M})$ or SI at $100 \mu \mathrm{M}$ in adhesion solution were incubated with $1 \times 10^{5}$ CFSE-stained, PMA-induced splenocytes at $37^{\circ} \mathrm{C}$ in $5 \% \mathrm{CO}_{2}$ for $45 \mathrm{~min}$ per well, as previously described. Non-adherent cells were gently aspirated, and wells were washed twice with $50 \mu \mathrm{L}$ of wash solution. Then, $100 \mu \mathrm{L}$ of wash solution was added to each well. Fluorescence was measured with excitation at $485 \mathrm{~nm}$ and emission at $535 \mathrm{~nm}$ using a plate reader (SpectraMax iD3; Molecular Devices) and SoftMax Pro (Molecular Devices). Each condition utilized triplicate wells. The fluorescence associated with splenocyte retention in wells containing ICAM-1-overexpressing bEnd.3 cells under each treatment condition was expressed as a percentage of fluorescence associated with non-ELP-treated splenocytes binding to cells, defined as $100 \%$, following Equation (1):

$$
\% \text { normalized }=(\text { treated }- \text { background }) /(\text { non-ELP treated-background }) * 100 \%
$$




\subsection{Antigen Presentation Assay}

For the isolation of $\mathrm{CD} 4+\mathrm{T}$ cells, splenocytes from C57BL/6J female mice were isolated as described above. A biotin antibody cocktail (anti-CD8a, CD11b, CD11c, CD19, CD24, CD45R/B220, CD49b, CD105, 1-A/I-E (MHC-II), TER-119/Erythroid) (BioLegend) was incubated with the cell suspension at $10 \mu \mathrm{L}$ per $1 \times 10^{7}$ cells in $100 \mu \mathrm{L}$ of buffer on ice for $15 \mathrm{~min}$. Following the incubation, streptavidin-coated magnetic beads (BioLegend) were added in an equal volume and incubated for 15 min again on ice. The solution was left to rest for $5 \mathrm{~min}$ in a magnetic stand (Stemcell) at room temperature. The supernatant containing unlabeled CD4+ T-cells was dispensed and counted on an automated cell counter. CD4+ T-cells were then labelled with CFSE, as previously described. CH27 B cells were grown in Roswell Park Memorial Institute Medium RPMI 1640 supplemented with $2 \mathrm{mM}$ L-Glutamine, $1 \times$ penicillin/streptomycin and $10 \%$ FBS. Prior to the mixed cell reaction, they were counted using a TC20 automated cell counter and spun down at $70 \times g$ for $10 \mathrm{~min}$. They were then resuspended in $\mathrm{CH} 27$ media containing MCC peptide $(15 \mu \mathrm{M})$ at $1 \times 10^{5}$ cells per $50 \mu \mathrm{L}$ and incubated for $30 \mathrm{~min}$ at $37^{\circ} \mathrm{C}$ in $5 \% \mathrm{CO}_{2}$. To identify the dose at which inhibition of T-cell proliferation was optimized, dilutions of IBP-SI $(200 \mu \mathrm{M})$ and SI $(200 \mu \mathrm{M})$ in CH27 medium containing CFSE-labelled CD4+ T-cells were prepared in clear 96 -well round bottom tissue culture plates. $\mathrm{CH} 27$ cell suspension containing MCC $(50 \mu \mathrm{L})$ and $50 \mu \mathrm{L}$ of ELP plus CD4+ T-cells were co-incubated at $37^{\circ} \mathrm{C}$ in $5 \% \mathrm{CO}_{2}$ for 5 days. Non-ELP treated CD4+ T-cells were also incubated 1:1 with MCC primed CH27 B-cells as a positive control. A final concentration of $1 \times 10^{5} \mathrm{CH} 27 \mathrm{~B}$-cells and $1 \times 10^{5} \mathrm{CD} 4+\mathrm{T}$-cells was used per treatment, and ELP concentrations of $100 \mu \mathrm{M}$ IBP-SI and SI were chosen for further investigation (a dose slightly above that of the $\mathrm{IC}_{50}$ ). Each treatment was done in triplicate wells. After 5 days, each well was collected into separate $1.7 \mathrm{~mL}$ tubes and counted with a cell counter. Alexa Fluor 700 anti-mouse CD3 antibody at $0.5 \mu \mathrm{g}$ per million cells was diluted in PBS and added to each tube. After $30 \mathrm{~min}$ incubation on ice, cells were pelleted down at $20^{\circ} \mathrm{C}$ at $2655 \times g$ for $8 \mathrm{~min}$ and resuspended in FACS buffer. Samples were read using FITC and APC-Cy7 channels for CFSE-labelled and CD3-labelled T-cells, respectively, on an LSR2 flow cytometer. Data were analyzed using FlowJo software. Data are shown as the percentage of cell proliferation for each treatment normalized to total proliferation from day 0 to day 5 for non-ELP treated positive controls, defined as $100 \%$.

\subsection{Statistics}

All data were expressed as mean \pm SD. Means from both groups were analysed using an unpaired two-tailed Student's t-test. A $p$ value of less than 0.05 was considered statistically significant.

\section{Conclusions}

This manuscript describes a multivalent protein polymer that targets ICAM- 1 in vitro and is internalized through ICAM-1 mediated endocytosis. As demonstrated using different measures of ICAM-1 and LFA-1 engagement, IBP-SI, but not the parent SI nanoparticle, inhibited the interaction between these key effectors of inflammation. Furthermore, IBP-SI, but not SI, prevented co-activation during antigen presentation, which is associated with T-cell proliferation. Future studies will explore the further utility and enhancement of this probe in vivo as well as its potential for therapeutic effect.

Author Contributions: Conceptualization, J.A.M. and S.F.H.-A.; methodology, P.-Y.H, Y.J., A.V., M.C.E., J.A.M. and S.F.H.-A.; validation and formal analysis, P.-Y.H, Y.J., A.V., M.C.E.; original manuscript draft, P.-Y.H, Y.J., A.V. and M.C.E; manuscript review and editing, M.C.E, J.A.M. and S.F.H.-A.; supervision, M.C.E, J.A.M. and S.F.H.-A.; project administration, S.F.H.-A.; funding acquisition, J.A.M. and S.F.H.-A. All authors have read and agreed to the published version of the manuscript.

Funding: This work was supported by R01 EY026635 to SHA and JAM, P30 EY029220 to the USC Department of Ophthalmology, EY 011386 to SHA, GM 114839 to JAM, and an unrestricted grant from Research to Prevent Blindness to the USC Department of Ophthalmology. Additional support was from P30 CA014089 to the USC Norris Comprehensive Cancer Center, and P30 DK048522 to the Liver Histology Core of the USC Research Center for Liver Diseases. 
Acknowledgments: We thank the staff at the USC NanoBiophysics Core Facility and the Translational Research Laboratory at the USC School of Pharmacy for their assistance. We sincerely thank Zhen Meng for the in vitro mouse LGAC preparations.

Conflicts of Interest: JAM and SHA are inventors on intellectual property related to this work which has been filed by their institutions.

\section{Abbreviations}

$\begin{array}{ll}\text { ATCC } & \text { American Type Culture Collection } \\ \text { CFSE } & \text { carboxyfluorescein diacetate succinimidyl ester } \\ \text { DAPI } & 4^{\prime} \text { 6-diamindino-2-phenylindole } \\ \text { DLS } & \text { dynamic light scattering } \\ \text { EDTA } & \begin{array}{l}\text { ethylenediaminetetraacetic acid } \\ \text { elastin-like polypeptide }\end{array} \\ \text { ELP } & \text { fluorescence-activated cell sorting } \\ \text { FACS } & \text { fragment crystallizable region } \\ \text { FC } & \text { intercellular adhesion molecule-1 } \\ \text { ICAM-1 } & \text { ICAM-1 binding peptide S48I48 } \\ \text { IBP-SI } & \text { interleukin-1 } \\ \text { IL-1 } & \text { lymphocyte function-associated antigen 1 } \\ \text { LFA-1 } & \text { lacrimal gland } \\ \text { LG } & \text { lacrimal gland acinar cell } \\ \text { LGAC } & \text { moth cytochrome C } \\ \text { MCC } & \text { Modified Eagle's Medium } \\ \text { MEM } & \text { major histocompatibility complex } \\ \text { MHC } & \text { mouse ICAM-1 } \\ \text { mICAM-1 } & \text { non-obese diabetic } \\ \text { NOD } & \text { poly lactic-co-glycolic acid } \\ \text { PLGA } & \text { phorbol 12-myristate 13-acetate } \\ \text { PMA } & \text { red fluorescent protein } \\ \text { RFP } & \text { rhodamine } \\ \text { rh } & \text { roswell park memorial institute medium } \\ \text { RPMI } & \text { salivary gland } \\ \text { SG } & \text { S48I48 } \\ \text { SI } & \text { Sjögrens' syndrome } \\ \text { SS } & \text { T cell receptor } \\ \text { TCR } & \text { tumor necrosis factor- } \alpha \\ \text { TNF- } \alpha & \\ & \end{array}$

\section{Appendix A}

A

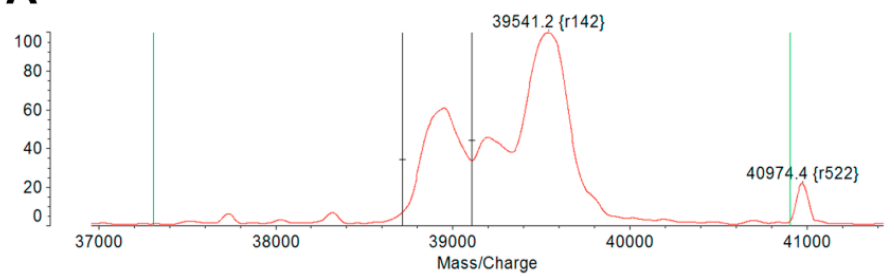

B

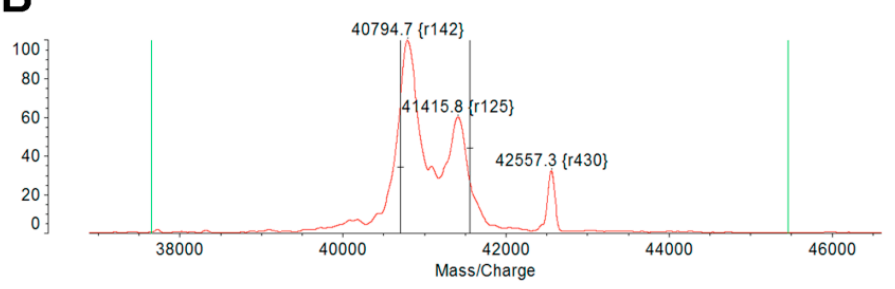

Figure A1. MALDI-TOF mass spectra of (A) SI and (B) IBP-SI. 


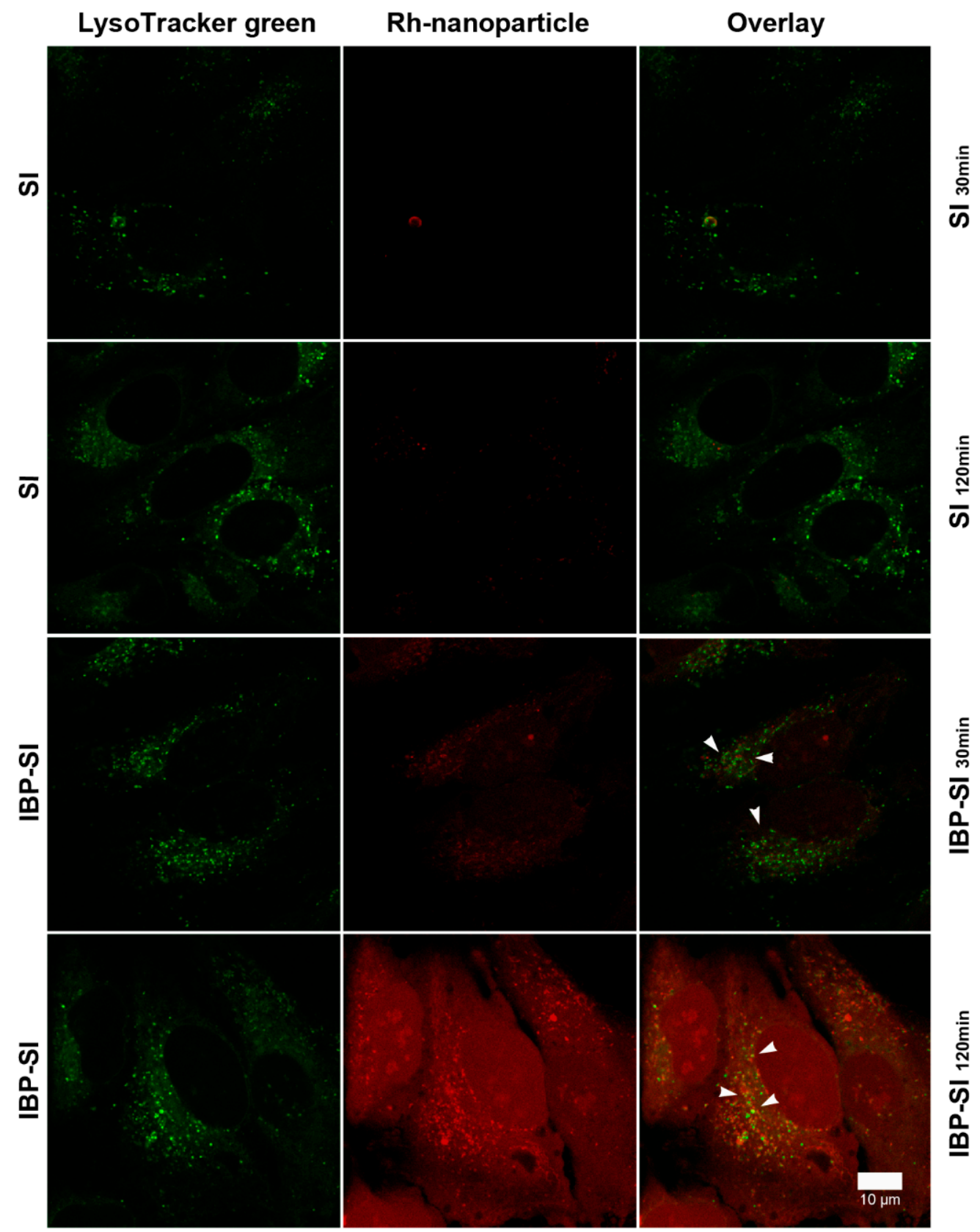

Figure A2. IBP-SI exhibits a cross-species targeting activity to human ICAM-1. HeLa cells were treated with rhodamine-labelled ELPs at $37^{\circ} \mathrm{C}$ for $30 \mathrm{~min}$ or $120 \mathrm{~min}$ prior to imaging using confocal fluorescence microscopy. LysoTracker Green $(70 \mathrm{nM})$ was used to delineate low $\mathrm{pH}$ compartments. At comparable time points, IBP-SI exhibited more detectable internalization than SI. Green, low $\mathrm{pH}$ compartments (late endosomes and lysosomes); red, ELP nanoparticles; white arrowheads, internalized ELP nanoparticles. Scale bar $=10 \mu \mathrm{m}$. 


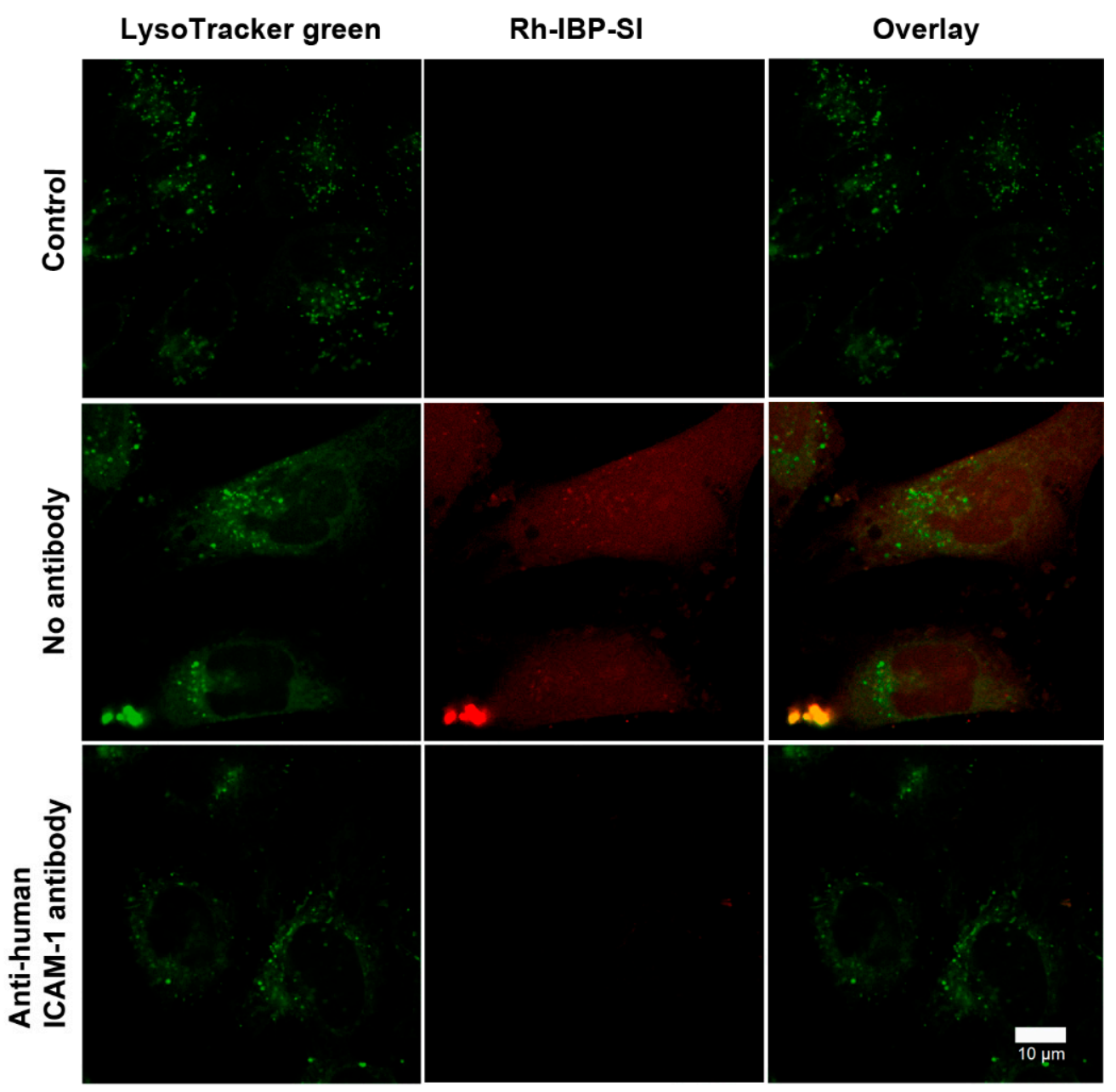

Figure A3. Binding and internalization of IBPSI into HeLa cells is prevented by ICAM-1 antibody. Competition binding assays were performed when Hela cells reached $70 \%$ confluence in $35 \mathrm{~mm}$ glass-bottomed dishes. Anti-human ICAM-1 antibody was diluted with warm medium at a 10 -fold dilution and incubated with Hela cells at $37^{\circ} \mathrm{C}$ for $30 \mathrm{~min}$. HeLa cells were then rinsed with warm medium and incubated with rhodamine-conjugated IBP-SI (red, $30 \mu \mathrm{M})$ and LysoTracker green (green, $75 \mathrm{nM}$ ). After $30 \mathrm{~min}$, the cells were rinsed with fresh warm medium and imaged using confocal microscopy. HeLa cells showed significant reduction in rhodamine signal after cells were incubated with anti-human ICAM-1 antibody. LysoTracker green was used to stain low $\mathrm{pH}$ lysosomes inside the cells. Scale bar: $10 \mu \mathrm{m}$.

Table A1. Temperature sensitive phase-transition parameters of SI and IBP-SI.

\begin{tabular}{ccc}
\hline \multirow{2}{*}{ Constructs } & Temperature-Concentration Phase & Diagram \\
\cline { 2 - 3 } & Slope, $\mathbf{m}\left({ }^{\circ} \mathbf{C L o g}(\mu \mathrm{M})\right)$ & Intercept, $\mathbf{b}\left({ }^{\circ} \mathbf{C}\right)$ \\
\hline SI $\left(T_{t 1}\right)$ & $-3.7 \pm 0.3$ & $32.4 \pm 0.4$ \\
\hline SI $\left(T_{t 2}\right)$ & $-4.0 \pm 0.5$ & $81.1 \pm 0.8$ \\
\hline IBP-SI $\left(T_{t 1}\right)$ & $-3.9 \pm 0.1$ & $31.4 \pm 0.2$ \\
\hline IBP-SI $\left(T_{t 2}\right)$ & $-4.1 \pm 0.3$ & $52.4 \pm 0.4$ \\
\hline
\end{tabular}




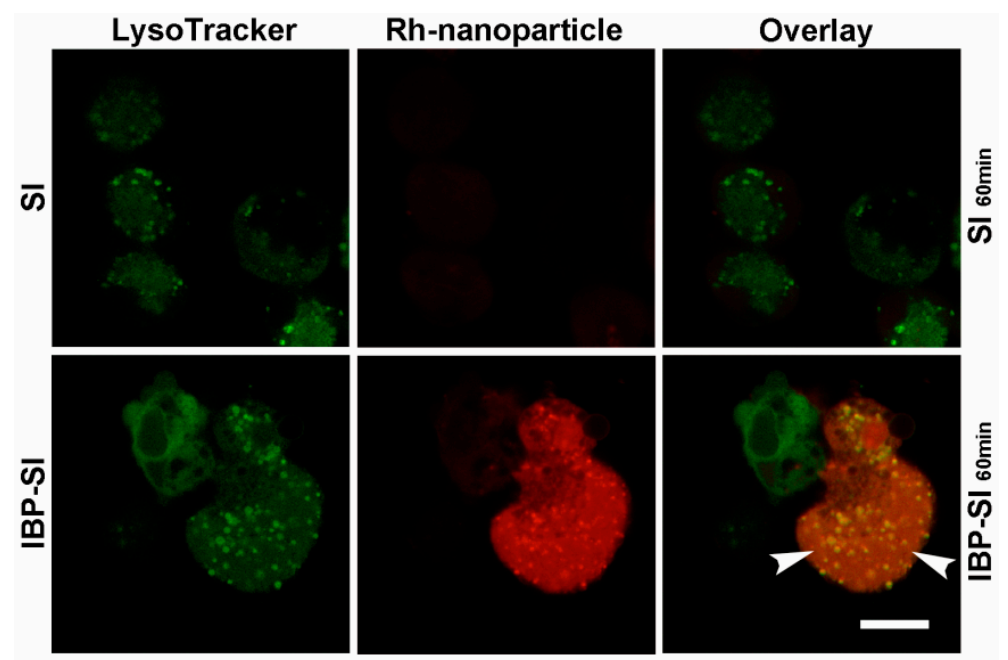

Figure A4. Addition of mouse ICAM-1 targeting peptide to SI enhances the ICAM-1 targeting specificity and internalization of SI in NOD LG acini. LGs from 12-14 week male NOD mice were removed and minced into $1 \mathrm{~mm}^{3}$ pieces with scalpels and sequentially grown in serum-free culture media containing $5 \mu \mathrm{g} / \mathrm{mL}$ laminin, $0.1 \mu \mathrm{M}$ carbachol, and $1 \mathrm{nM}$ thyroxine. Cells were seeded on a Matrigel ${ }^{\mathrm{TM}}$ coat for live cell imaging on $35 \mathrm{~mm}$ glass-bottomed dishes at $6 \times 10^{6}$ cells per dish and incubated at $37^{\circ} \mathrm{C}$ for $2-3 \mathrm{~h}$ prior to experiments. Acini were then treated with $30 \mu \mathrm{M}$ rhodamine-labeled (rh)-SI or IBP-SI at $37^{\circ} \mathrm{C}$ for $1 \mathrm{~h}$. Rh-IBP-SI (red) exhibits significantly higher surface binding, internalization, and co-localization with LysoTracker (green), a biomarker for low $\mathrm{pH}$ compartments, in NOD LG acini than its SI counterpart. White arrowheads indicate the co-localization of IBP-SI and LysoTracker. Scale bar $=10 \mu \mathrm{m}$.

\section{References}

1. Mavragani, C.P.; Moutsopoulos, H.M. Sjogren's syndrome. Annu. Rev. Pathol. 2014, 9, 273-285. [CrossRef] [PubMed]

2. Nocturne, G.; Mariette, X. Sjogren Syndrome-associated lymphomas: An update on pathogenesis and management. Br. J. Haematol. 2015, 168, 317-327. [CrossRef] [PubMed]

3. Nikolov, N.P.; Illei, G.G. Pathogenesis of Sjögren's syndrome. Curr. Opin. Rheumatol. 2009, 21, 465-470. [CrossRef] [PubMed]

4. Stern, M.E.; Schaumburg, C.S.; Dana, R.; Calonge, M.; Niederkorn, J.Y.; Pflugfelder, S.C. Autoimmunity at the ocular surface: Pathogenesis and regulation. Mucosal Immunol. 2010, 3, 425-442. [CrossRef] [PubMed]

5. Foulks, G.N.; Forstot, S.L.; Donshik, P.C.; Forstot, J.Z.; Goldstein, M.H.; Lemp, M.A.; Nelson, J.D.; Nichols, K.K.; Pflugfelder, S.C.; Tanzer, J.M.; et al. Clinical Guidelines for Management of Dry Eye Associated with Sjogren Disease. Ocul. Surf. 2015, 13, 118-132. [CrossRef] [PubMed]

6. Vivino, F.B.; Carsons, S.E.; Foulks, G.; Daniels, T.E.; Parke, A.; Brennan, M.T.; Forstot, S.L.; Scofield, R.H.; Hammitt, K.M. New Treatment Guidelines for Sjogren's Disease. Rheum. Dis. Clin. N. Am. 2016, 42, 531-551. [CrossRef]

7. Shah, M.; Edman, M.C.; Janga, S.R.; Shi, P.; Dhandhukia, J.; Liu, S.; Louie, S.G.; Rodgers, K.; Mackay, J.A.; Hamm-Alvarez, S.F. A rapamycin-binding protein polymer nanoparticle shows potent therapeutic activity in suppressing autoimmune dacryoadenitis in a mouse model of Sjogren's syndrome. J. Control. Release Off. J. Control. Release Soc. 2013, 171, 269-279. [CrossRef]

8. Shah, M.; Edman, M.C.; Reddy Janga, S.; Yarber, F.; Meng, Z.; Klinngam, W.; Bushman, J.; Ma, T.; Liu, S.; Louie, S.; et al. Rapamycin Eye Drops Suppress Lacrimal Gland Inflammation In a Murine Model of Sjogren's Syndrome. Investig. Ophthalmol. Vis. Sci. 2017, 58, 372-385. [CrossRef]

9. Bella, J.; Kolatkar, P.R.; Marlor, C.W.; Greve, J.M.; Rossmann, M.G. The structure of the two amino-terminal domains of human ICAM-1 suggests how it functions as a rhinovirus receptor and as an LFA-1 integrin ligand. Proc. Natl. Acad. Sci. USA 1998, 95, 4140-4145. [CrossRef] 
10. Giorelli, M.; De Blasi, A.; Defazio, G.; Avolio, C.; Iacovelli, L.; Livrea, P.; Trojano, M. Differential regulation of membrane bound and soluble ICAM 1 in human endothelium and blood mononuclear cells: Effects of interferon beta-1a. Cell Commun. Adhes. 2002, 9, 259-272. [CrossRef]

11. Min, J.K.; Kim, Y.M.; Kim, S.W.; Kwon, M.C.; Kong, Y.Y.; Hwang, I.K.; Won, M.H.; Rho, J.; Kwon, Y.G. TNF-related activation-induced cytokine enhances leukocyte adhesiveness: Induction of ICAM-1 and VCAM-1 via TNF receptor-associated factor and protein kinase C-dependent NF-kappaB activation in endothelial cells. J. Immunol. (Baltim. Md. 1950) 2005, 175, 531-540. [CrossRef] [PubMed]

12. Long, E.O. ICAM-1: Getting a grip on leukocyte adhesion. J. Immunol. (Baltim. Md. 1950) 2011, 186, 5021-5023. [CrossRef] [PubMed]

13. Gross, M.D.; Bielinski, S.J.; Suarez-Lopez, J.R.; Reiner, A.P.; Bailey, K.; Thyagarajan, B.; Carr, J.J.; Duprez, D.A.; Jacobs, D.R., Jr. Circulating soluble intercellular adhesion molecule 1 and subclinical atherosclerosis: The Coronary Artery Risk Development in Young Adults Study. Clin. Chem. 2012, 58, 411-420. [CrossRef] [PubMed]

14. Fotis, L.; Agrogiannis, G.; Vlachos, I.S.; Pantopoulou, A.; Margoni, A.; Kostaki, M.; Verikokos, C.; Tzivras, D.; Mikhailidis, D.P.; Perrea, D. Intercellular adhesion molecule (ICAM)-1 and vascular cell adhesion molecule (VCAM)-1 at the early stages of atherosclerosis in a rat model. In Vivo 2012, 26, 243-250. [PubMed]

15. Mendivil, C.O.; Robles-Osorio, L.; Horton, E.S.; Hamdy, O.; Caballero, A.E. Young Hispanics at risk of type 2 diabetes display endothelial activation, subclinical inflammation and alterations of coagulation and fibrinolysis. Diabetol. Metab. Syndr. 2013, 5, 37. [CrossRef]

16. Jing, L.; Wang, J.G.; Zhang, J.Z.; Cao, C.X.; Chang, Y.; Dong, J.D.; Guo, F.Y.; Li, P.A. Upregulation of ICAM-1 in diabetic rats after transient forebrain ischemia and reperfusion injury. J. Inflamm. 2014, 11, 35. [CrossRef]

17. Adukpo, S.; Kusi, K.A.; Ofori, M.F.; Tetteh, J.K.; Amoako-Sakyi, D.; Goka, B.Q.; Adjei, G.O.; Edoh, D.A.; Akanmori, B.D.; Gyan, B.A.; et al. High plasma levels of soluble intercellular adhesion molecule (ICAM)-1 are associated with cerebral malaria. PLoS ONE 2013, 8, e84181. [CrossRef]

18. Stem, M.E.; Gao, J.; Morgan, G.A.; Brees, D.; Schwalb, T.A.; Humphreys-Behr, M.; Smith, J.A. The role of ICAM-1 as a signal protein for predisposition of ocular surface inflammation. Adv. Exp. Med. Biol. 2002, $506,753-759$.

19. Gao, J.; Morgan, G.; Tieu, D.D.; Schwalb, T.A.; Ngo, M.; Stern, M.E. ICAM-1: Its role in the pathophysiology of immune activation in the MRL/LPR mouse. Adv. Exp. Med. Biol. 2002, 506, 777-781.

20. Ju, Y.; Guo, H.; Yarber, F.; Edman, M.C.; Peddi, S.; Janga, S.R.; MacKay, J.A.; Hamm-Alvarez, S.F. Molecular Targeting of Immunosuppressants Using a Bifunctional Elastin-Like Polypeptide. Bioconj. Chem. 2019, 30, 2358-2372. [CrossRef]

21. Zhong, M.; Hanan, E.J.; Shen, W.; Bui, M.; Arkin, M.R.; Barr, K.J.; Evanchik, M.J.; Hoch, U.; Hyde, J.; Martell, J.R.; et al. Structure-activity relationship (SAR) of the alpha-amino acid residue of potent tetrahydroisoquinoline (THIQ)-derived LFA-1/ICAM-1 antagonists. Bioorganic Med. Chem. Lett. 2011, 21, 307-310. [CrossRef] [PubMed]

22. Yusuf-Makagiansar, H.; Anderson, M.E.; Yakovleva, T.V.; Murray, J.S.; Siahaan, T.J. Inhibition of LFA-1/ICAM-1 and VLA-4/VCAM-1 as a therapeutic approach to inflammation and autoimmune diseases. Med. Res. Rev. 2002, 22, 146-167. [CrossRef] [PubMed]

23. Nicolls, M.R.; Gill, R.G. LFA-1 (CD11a) as a therapeutic target. Am. J. Transplant. Off. J. Am. Soc. Transplant. Am. Soc.Transplant Surg. 2006, 6, 27-36. [CrossRef] [PubMed]

24. Semba, C.P.; Gadek, T.R. Development of lifitegrast: A novel T-cell inhibitor for the treatment of dry eye disease. Clin. Ophthalmol. 2016, 10, 1083-1094. [CrossRef]

25. Belizaire, A.K.; Tchistiakova, L.; St-Pierre, Y.; Alakhov, V. Identification of a murine ICAM-1-specific peptide by subtractive phage library selection on cells. Biochem. Biophys. Res. Commun. 2003, 309, 625-630. [CrossRef]

26. Urry, D. Physical chemistry of biological free energy transduction as demonstrated by elastic protein-based polymers. J. Phys. Chem. B 1997, 101, 11007-11028. [CrossRef]

27. Janib, S.M.; Gustafson, J.A.; Minea, R.O.; Swenson, S.D.; Liu, S.; Pastuszka, M.K.; Lock, L.L.; Cui, H.; Markland, F.S.; Conti, P.S.; et al. Multimeric disintegrin protein polymer fusions that target tumor vasculature. Biomacromolecules 2014, 15, 2347-2358. [CrossRef]

28. Shi, P.; Aluri, S.; Lin, Y.A.; Shah, M.; Edman, M.; Dhandhukia, J.; Cui, H.; MacKay, J.A. Elastin-based protein polymer nanoparticles carrying drug at both corona and core suppress tumor growth in vivo. J. Control. Release Off. J.Control. Release Soc. 2013, 171, 330-338. [CrossRef] 
29. Hsueh, P.; Edman, M.C.; Sun, G.; Shi, P.; Xu, S.; Lin, Y.; Cui, H.; Hamm-Alvarez, S.F.; Andrew MacKay, J. Tear-mediated delivery of nanoparticles through transcytosis of the lacrimal gland. J. Control. Release Off. J. Control. Release Soc. 2015, 208, 2-13. [CrossRef]

30. Wang, W.; Despanie, J.; Shi, P.; Edman-Woolcott, M.C.; Lin, Y.; Cui, H.; Heur, J.M.; Fini, M.E.; Hamm-Alvarez, S.F.; MacKay, J.A. Lacritin-mediated regeneration of the corneal epithelia by protein polymer nanoparticles. J. Mater. Chem. B Mater. Biol. Med. 2014, 2, 8131-8141. [CrossRef]

31. Muro, S.; Wiewrodt, R.; Thomas, A.; Koniaris, L.; Albelda, S.M.; Muzykantov, V.R.; Koval, M. A novel endocytic pathway induced by clustering endothelial ICAM-1 or PECAM-1. J. Cell Sci. 2003, 116, 1599-1609. [CrossRef] [PubMed]

32. Muro, S.; Gajewski, C.; Koval, M.; Muzykantov, V.R. ICAM-1 recycling in endothelial cells: A novel pathway for sustained intracellular delivery and prolonged effects of drugs. Blood 2005, 105, 650-658. [CrossRef] [PubMed]

33. Lee, B.H.; Tudares, M.A.; Nguyen, C.Q. Sjogren's syndrome: An old tale with a new twist. Arch. Immunol. Et Ther. Exp. 2009, 57, 57-66. [CrossRef] [PubMed]

34. Weber, K.S.; Klickstein, L.B.; Weber, C. Specific activation of leukocyte beta2 integrins lymphocyte function-associated antigen-1 and Mac- 1 by chemokines mediated by distinct pathways via the alpha subunit cytoplasmic domains. Mol. Biol. Cell 1999, 10, 861-873. [CrossRef]

35. Rey-Ladino, J.A.; Huber, M.; Liu, L.; Damen, J.E.; Krystal, G.; Takei, F. The SH2-containing inositol-5' -phosphatase enhances LFA-1-mediated cell adhesion and defines two signaling pathways for LFA-1 activation. J. Immunol. (Baltim. Md. 1950) 1999, 162, 5792-5799.

36. Kandula, S.; Abraham, C. LFA-1 on CD4+ T Cells Is Required for Optimal Antigen-Dependent Activation In Vivo. J. Immunol. 2004, 173, 4443. [CrossRef]

37. Mesri, M.; Liversidge, J.; Forrester, J.V. ICAM-1/LFA-1 interactions in T-lymphocyte activation and adhesion to cells of the blood-retina barrier in the rat. Immunology 1994, 83, 52-57.

38. Varga, G.; Nippe, N.; Balkow, S.; Peters, T.; Wild, M.K.; Seeliger, S.; Beissert, S.; Krummen, M.; Roth, J.; Sunderkötter, C.; et al. LFA-1 Contributes to Signal I of T-Cell Activation and to the Production of Th1 Cytokines. J. Investig. Dermatol. 2010, 130, 1005-1012. [CrossRef]

39. Abraham, C.; Griffith, J.; Miller, J. The Dependence for Leukocyte Function-Associated Antigen-1/ICAM-1 Interactions in T Cell Activation Cannot Be Overcome by Expression of High Density TCR Ligand. J. Immunol. 1999, 162, 4399-4405.

40. Pflugfelder, S.C.; Stern, M.; Zhang, S.; Shojaei, A. LFA-1/ICAM-1 Interaction as a Therapeutic Target in Dry Eye Disease. J. Ocul. Pharmacol. Ther. Off. J. Assoc. Ocul. Pharmacol. Ther. 2017, 33, 5-12. [CrossRef]

41. Whitcup, S.M.; Chan, C.-C.; Kozhich, A.T.; Magone, M.T. Blocking ICAM-1 (CD54) and LFA-1 (CD11a) Inhibits Experimental Allergic Conjunctivitis. Clin. Immunol. 1999, 93, 107-113. [CrossRef] [PubMed]

42. Roybal, K.T.; Mace, E.M.; Mantell, J.M.; Verkade, P.; Orange, J.S.; Wülfing, C. Early Signaling in Primary T Cells Activated by Antigen Presenting Cells Is Associated with a Deep and Transient Lamellal Actin Network. PLoS ONE 2015, 10, e0133299. [CrossRef] [PubMed]

43. Wülfing, C.; Sjaastad, M.D.; Davis, M.M. Visualizing the dynamics of T cell activation: Intracellular adhesion molecule 1 migrates rapidly to the T cell/B cell interface and acts to sustain calcium levels. Proc. Natl. Acad. Sci. USA 1998, 95, 6302-6307. [CrossRef] [PubMed]

44. Garnacho, C.; Serrano, D.; Muro, S. A fibrinogen-derived peptide provides intercellular adhesion molecule-1-specific targeting and intraendothelial transport of polymer nanocarriers in human cell cultures and mice. J. Pharmacol. Exp. Ther. 2012, 340, 638-647. [CrossRef]

45. Zhang, N.; Chittasupho, C.; Duangrat, C.; Siahaan, T.J.; Berkland, C. PLGA nanoparticle-peptide conjugate effectively targets intercellular cell-adhesion molecule-1. Bioconj. Chem. 2008, 19, 145-152. [CrossRef]

46. Muro, S.; Cui, X.; Gajewski, C.; Murciano, J.C.; Muzykantov, V.R.; Koval, M. Slow intracellular trafficking of catalase nanoparticles targeted to ICAM-1 protects endothelial cells from oxidative stress. Am. J. Physiol. Cell Physiol. 2003, 285, C1339-C1347. [CrossRef]

47. Muro, S.; Schuchman, E.H.; Muzykantov, V.R. Lysosomal enzyme delivery by ICAM-1-targeted nanocarriers bypassing glycosylation- and clathrin-dependent endocytosis. Mol. Ther. J. Am. Soc. Gene Ther. 2006, 13, 135-141. [CrossRef] 
48. Rossin, R.; Muro, S.; Welch, M.J.; Muzykantov, V.R.; Schuster, D.P. In vivo imaging of 64Cu-labeled polymer nanoparticles targeted to the lung endothelium. J. Nucl. Med. Off. Publ. Soc. Nucl. Med. 2008, 49, 103-111. [CrossRef]

49. Chittasupho, C.; Siahaan, T.J.; Vines, C.M.; Berkland, C. Autoimmune therapies targeting costimulation and emerging trends in multivalent therapeutics. Ther. Deliv. 2011, 2, 873-889. [CrossRef]

50. Huang, M.; Matthews, K.; Siahaan, T.J.; Kevil, C.G. Alpha L-integrin I domain cyclic peptide antagonist selectively inhibits T cell adhesion to pancreatic islet microvascular endothelium. Am. J. Physiol. Gastrointest. Liver Physiol. 2005, 288, G67-G73. [CrossRef]

51. Tibbetts, S.A.; Seetharama Jois, D.; Siahaan, T.J.; Benedict, S.H.; Chan, M.A. Linear and cyclic LFA-1 and ICAM-1 peptides inhibit T cell adhesion and function. Peptides 2000, 21, 1161-1167. [CrossRef]

52. Yusuf-Makagiansar, H.; Yakovleva, T.V.; Tejo, B.A.; Jones, K.; Hu, Y.; Verkhivker, G.M.; Audus, K.L.; Siahaan, T.J. Sequence recognition of alpha-LFA-1-derived peptides by ICAM-1 cell receptors: Inhibitors of T-cell adhesion. Chem. Biol. Drug Des. 2007, 70, 237-246. [CrossRef]

53. Shannon, J.P.; Silva, M.V.; Brown, D.C.; Larson, R.S. Novel cyclic peptide inhibits intercellular adhesion molecule-1-mediated cell aggregation. J. Pept. Res. Off. J. Am. Pept. Soc. 2001, 58, 140-150. [CrossRef]

54. Semba, C.P.; Torkildsen, G.L.; Lonsdale, J.D.; McLaurin, E.B.; Geffin, J.A.; Mundorf, T.K.; Kennedy, K.S.; Ousler, G.W. A phase 2 randomized, double-masked, placebo-controlled study of a novel integrin antagonist (SAR 1118) for the treatment of dry eye. Am. J. Ophthalmol. 2012, 153, 1050-1060.e1.

55. Sheppard, J.D.; Torkildsen, G.L.; Lonsdale, J.D.; D’Ambrosio, F.A., Jr.; McLaurin, E.B.; Eiferman, R.A.; Kennedy, K.S.; Semba, C.P. Lifitegrast ophthalmic solution 5.0\% for treatment of dry eye disease: Results of the OPUS-1 phase 3 study. Ophthalmology 2014, 121, 475-483. [CrossRef]

56. Muro, S. A DNA-Device that Mediates Selective Endosomal Escape and Intracellular Delivery of Drugs and Biologicals. Adv. Funct. Mater. 2014, 24, 2899-2906. [CrossRef]

57. MacEwan, S.R.; Chilkoti, A. Applications of elastin-like polypeptides in drug delivery. J. Control. Release Off. J. Control. Release Soc. 2014, 190, 314-330. [CrossRef]

58. Baiu, D.C.; Prechl, J.; Tchorbanov, A.; Molina, H.D.; Erdei, A.; Sulica, A.; Capel, P.J.; Hazenbos, W.L. Modulation of the humoral immune response by antibody-mediated antigen targeting to complement receptors and Fc receptors. J. Immunol. (Baltim., Md. 1950) 1999, 162, 3125-3130.

59. Aina, O.H.; Sroka, T.C.; Chen, M.L.; Lam, K.S. Therapeutic cancer targeting peptides. Biopolymers 2002, 66, 184-199. [CrossRef]

60. Camacho, C.J.; Katsumata, Y.; Ascherman, D.P. Structural and thermodynamic approach to peptide immunogenicity. PLoS Comput. Biol. 2008, 4, e1000231. [CrossRef]

61. National Research Council (US) Committee. Guide for the Care and Use of Laboratory Animals, 8th ed.; National Academies Press (US): Washington, DC, USA, 2011.

62. Sun, G.; Hsueh, P.Y.; Janib, S.M.; Hamm-Alvarez, S.; MacKay, J.A. Design and cellular internalization of genetically engineered polypeptide nanoparticles displaying adenovirus knob domain. J. Control. Release Off. J. Control. Release Soc. 2011, 155, 218-226. [CrossRef] [PubMed]

(C) 2020 by the authors. Licensee MDPI, Basel, Switzerland. This article is an open access article distributed under the terms and conditions of the Creative Commons Attribution (CC BY) license (http://creativecommons.org/licenses/by/4.0/). 